\title{
Analysis of corporate sustainability performance and corporate financial performance causal linkage in the Indian context
}

\author{
Milind Kumar Jha ${ }^{1 *}$ (D) and K. Rangarajan²
}

\author{
*Correspondence: milinddbg@ \\ gmail.com; milind_phd17@iift.edu \\ IIndian Institute of Foreign Trade, \\ New Delhi, India \\ Full list of author information is \\ available at the end of the article
}

\begin{abstract}
This paper aims to explore the relationship between corporate sustainability performance (CSP) and corporate firm performance (CFP) for a sample of the top 500 Indian firms covering the period from 2008 to 2018. CSP variables have been considered at both aggregate and disaggregate levels of environmental, social and governance performance. CFP has been evaluated in both accounting and marketbased measures. Rigorous statistical methods have been used to evaluate the bidirectional causality and intensity of the CSP-CFP relationship using the Granger causality test and multiple regression for panel data. A sectoral level trend analysis is presented dividing the firms in various industries and classifying them in ESI vs nonESI sectors. The findings indicate the absence of causality among CSP and CFP variables in either direction and suggest that the CSP-CFP linkage is mostly insignificant for Indian firms at the aggregate level. At an individual level, some negative association is found between CSP and CFP. This relationship has an adverse impact on CSP-CFP linkage in both cases, which means that Indian firms don't get the financial performance benefits of investments done for sustainability. Our findings with mostly insignificant results for this relation also means that firms with higher or lower CSP on ESG dimensions will perform likewise in terms of CFP. The findings have practical implications for corporates, academicians, and policymakers alike given sustainability as a high focus area for all.
\end{abstract}

Keywords: Corporate sustainability performance, Corporate financial performance, ESG, Indian firms, CSP, CFP, Granger causality

\section{Introduction}

Business is a remarkable social invention (Jensen and Meckling 1976) of the contemporary world, consisting of firms that are a part of and emanate from society (Branco and Rodrigues 2006). Businesses face sustainability compliance pressure from both internal and external stakeholders (Wilkinson et al. 2001) and hence adopt relevant approaches to avoid customers and public disfavor (Davis 1973). Sustainability as a concept is grounded in creating a balance between the principles of integrity

(c) The Author(s). 2020 Open Access This article is licensed under a Creative Commons Attribution 4.0 International License, which permits use, sharing, adaptation, distribution and reproduction in any medium or format, as long as you give appropriate credit to the original author(s) and the source, provide a link to the Creative Commons licence, and indicate if changes were made. The images or other third party material in this article are included in the article's Creative Commons licence, unless indicated otherwise in a credit line to the material. If material is not included in the article's Creative Commons licence and your intended use is not permitted by statutory regulation or exceeds the permitted use, you will need to obtain permission directly from the copyright holder. To view a copy of this licence, visit http://creativecommons.org/licenses/by/4.0/. 
(environment), equity (society), and prosperity (economy) (Bansal 2005), later ideated as "Triple bottom line"(TBL) concept (Elkington 2011). Among these three goals, pursuing the first two is likely to enhance the third goal (Placet et al. 2005), aligning with the value maximization (Appelbaum et al. 2016) goal of the firm. However, many times the role business plays for sustainability is criticized for being driven by a political and profit-driven agenda (Luke 2013).

India is a rapidly growing country and envisions to move swiftly on developmental parameters. Though a developing country, it has joined the bigger club on both political and economic fronts. As India contributes to the world GDP with high growth business activities, it needs to play a substantial role in sustainability too. India is an amalgamation of multiple challenges as well as opportunities across the tripartite core structure of sustainable development (Von Hauff and Veling 2018). The country is increasingly playing a global role because of many strengths, such as the global presence of Indian diaspora, entrepreneurial interest and culture, robust confidence from investors, highly skilled english-speaking personnel, stable political scenarios, and supportive government initiatives (Agrawal et al. 2017). As a large and young population presents a massive opportunity for this country to contribute in all dimensions, it is equally lagged because of various challenges. Recently, equal focus is given on sustainability apart from the financial aspects of growth and performance. Indian government launched programs like Swachh Bharat Abhiyan (focused on cleanliness and sanitation), Pradhan Mantri Ujjwala Yojna (focused on less emissions in household cooking), Pradhan Mantri Jan Dhan Yojana (focused on financial inclusiveness), Pradhan Mantri Jan Arogya Yojna (focused on universal health coverage) and No single-use plastic, which are directed towards various dimensions of environment and social factors.

The predominant driver for CSR (Corporate Social Responsibility) or sustainability in Indian context is the moral imperative (Dhanesh 2015). As per the Vedic philosophy prevalent in Indian society, the principle role of money is to serve the needs of the community and for the welfare of others (Sharma 2009). CSR in India is a well-established phenomenon as per its historical tradition and culture derived from its value system and has evolved with time from being driven by religious aspects during pre-industrial periods to the strategic approach taken by corporates today; however, there is a significant room for improvement (Jain and Winner 2016). The Indian government is projecting CSR to enhance economic equality in India and advises the corporates to use CSR for positioning the positive image to compensate for the social/environmental damages caused in the course of business activities (Sharma 2013). Changes in Companies Act 2013 that mandates a particular class of firms to devote a minimum of $2 \%$ of the last 3 years' average profit towards CSR provides an opportunity for organizations to transition from philanthropic CSR to strategic CSR (Jayakumar 2016). However, it is criticized for being an instrument used by the government to abdicate its social responsibility (Deodhar 2016) by directly putting a tax of $2 \%$ on corporates rather than mandating them to spend it on CSR activities.

Sustainability and its relationship with organizational performance have remained a prominent area of research with a lot of focus from academic researchers. We are extending this research using the latest and exhaustive set of data where the current study attempts to understand the overall status of corporate sustainability performance (CSP) for Indian firms in terms of their efforts towards environmental, social and governance 
dimensions aka, ESG while trying to understand its impact on corporate financial performance (CFP). In the context of corporate engagement, the role of corporate governance is equally important that needs to be taken into account while evaluating the CSP of a firm. This study evaluates the causality between CSP and CFP in the Indian context using rigorous statistical methods. An imperative reason for conducting this study in India is a dearth of literature focusing on CSP-CFP causality as most of such studies have been done for firms in developed countries.

The study seeks to explore the following research questions in the Indian context:

RQ1: How are different dimensions of CSP associated with CFP of Indian firms?

RQ2: Is there an existence of causality between CSP-CFP for Indian firms?

RQ3: How does the CSP-CFP relationship vary for different types of industries in India?

\section{Literature review and hypothesis development}

\section{Theoretical background}

Traditionally, sustainability was used as a synonym for CSR. However, it has changed in recent decades, where CSR is recognized as one way of achieving sustainability with a clear business case for the same (Carroll and Shabana 2010). The conflicting arguments on the primary role and responsibilities of corporate management are based on shareholder theory (Friedman 1962) vs. stakeholder theory (Freeman 2010) driven by their approach towards shareholders (increase economic capital only) or the stakeholders (increase economic, ecological, and social capital) respectively. This relationship has moved from CSR as a coherent framework for the field of business and society (Wood 1991) to corporate sustainability to sustainable development in terms of its managerial, organizational or societal approach (Steurer et al. 2005). In general, sustainability is envisioned as eco-oriented (nature and its elements), justice-oriented (civil rights, equity, intra-inter-generational justice), or marketoriented (attributes influenced by corporates) (Greenberg 2013), though the corporate sustainability comes into the picture because of growing economies, environment regulation and focus towards social justice (Christofi et al. 2012).

The overall performance of a corporate today includes its performance along different non-financial dimensions of sustainability using the CSP construct that differs from the traditional firm performance referred to as CFP. CSP is a multidimensional and complex construct with ambiguity and pluralistic goals (Searcy 2012) driven by contextual context and emphasizes a firm's responsibilities and its responsiveness towards its multiple stakeholders (Wood 1991). Even though CSP doesn't have an agreed definition, it is conceptualized with a focus on social issues and stakeholder management (Landi and Sciarelli 2019). Good CSP represents a valuable strategic asset that can help in enhancing the reputation and enjoying privileged access to factor and product markets (O'shaughnessy et al. 2007). Top leadership recognizes the importance of CSP in core business from the perspective of environmental, social and governance issues (Lacy and Hayward 2011). Investors prefer firms with good CSP as a signal of the firm having capabilities that will enhance its value (Lourenço et al. 2014).

\section{CSP conceptualization}

One of the major issues in evaluating CSP-CFP relationship is CSP measurement since it is a multi-dimensional construct. This construct is subjective and highly fragmented 
in the literature (Peloza 2009) spread across dimensions that are both relevant and necessary for deriving effective conclusions (Waddock and Graves 1997). Many researchers have suggested models for CSP measurement, but most of them are focused either on individual dimensions of sustainability (Deswanto and Siregar 2018; Famiyeh 2017; Lee and Pati 2012), based on GRI/DJSI indices (Delai and Takahashi 2011), or specific sector indicators (Ahmad et al. 2019). The lack of convergence on a CSP model is because of divergent focus on dimensions, lack of consensus (Sikdar 2003), and quality of disclosures (Epstein and Bohuvac 2014). Luo et al. 2015 analyzed this relationship from the analyst recommendation perspective using both ESG and KLD attributes for CSP and suggested that now analysts demand more information on environmental and social information while valuing a firm.

Measuring sustainability is a crucial activity (Delai and Takahashi 2011), and there is no standard definition of CSP that can be adequately adopted (Van Beurden and Gössling 2008). Nagel et al. (2017) posited that sustainability still lacks a single, generally accepted best practice after comparing the KPIs for many disclosure standards. In CSPCFP research, many authors focused on either ecological or environmental dimensions while doing their research on sustainability (Gibson 2012) and many researchers have also taken the aggregate measurement approach encapsulating multiple dimensions of CSP. Most of the times CSP is based on the TBL aspect covering environmental and social dimensions. However, numerous scholars have used ESG (ecological, social, and governance) factors for assessment of CSP (Landi and Sciarelli 2019; Tamimi and Sebastianelli 2017; Tyagi and Sharma 2013). In the Indian context also, recent literature has used ESG dimensions in various ways for evaluation of CSP (Duque-Grisales and Aguilera-Caracuel 2019; Ionescu et al. 2019; Buallay 2019; Dalal and Thaker 2019; Sung Kim and Oh 2019).

Corporate Governance (CG) is a core aspect of a business, that describes how firms are managed and help the managers in decision making aligned with the goal of their stakeholders. Effective CG enhances a firm's success by improving its CFP (Yusoff and Alhaji 2012). The initial discussion on CG is driven by Agency theory (Jensen and Meckling 1976), focused on ownership and control segregation and the principal-agent problem existing in governance. Stewardship theory (Davis et al. 1997) is an anti-thesis to agency theory because of the belief that the manager's goals are aligned with those of shareholders. But the best theories that explain the need of an effective CG are stakeholder theory (Freeman 2010) and legitimacy theory (Suchman 1995) which are focused on issues concerning the stakeholders for a business and its contract with the society aligned with the norms, values, beliefs, and definitions. The legitimacy of a firm is vital for its existence and progress (Du and Vieira 2012) and is heavily dependent on the perception among the contextual environment; it plays a role. Thus, the CG aspect becomes an essential constituent of CSP evaluation.

Investors seeking transparency look for some indicator from third party agencies that is a combination of past performance and evaluation of action that can influence future performance (Chatterji et al. 2009) where ESG rating scores seem an appropriate measure to be used as a proxy for CSP. ESG refers to the three key factors used in investment markets for evaluation of a firm's performance on non-financial attributes (Atan et al. 2018), which is of great interest to stakeholders to understand how a firm is performing along these dimensions. These factors are becoming increasingly critical for investors and different stakeholders in the contemporary world with dynamic changes to 
these factors (ESG Data 2019). Institutional investors, asset managers, financial institutions rely on this ESG-score provided by various third-party providers for assessing the CSP of a firm or industry (Huber et al. 2017).

ESG indicators show additional aspects of a firm's non-financial performance that is not reflected in financial reports (Kengkathran 2018) and are critical indicators for a firm's CSP. These scores can be important indicators for investors who can make their investment decisions based on that and also for other stakeholders to provide evaluation and comparability of the sustainability performance of a firm on the different dimensions of ESG. Disclosure on ESG parameters can reduce the information gap between a firm and its stakeholders (Stubbs and Rogers 2013) and hence is very important for evaluating a firm from an investment perspective. ESG rating agencies provide accurate third-party information to investors for CSP evaluation, which is used as a proxy for assessing "Management Quality" (Tamimi and Sebastianelli 2017) and indicates investors regarding socially responsible behavior of a firm (Chatterji et al. 2009). However, many times rating from such agencies is also questioned because of the subjectivity and lack of transparency owing to the difference in parameters and weights used during the assessment.

\section{CSP-CFP linkage}

There is extensive but inconclusive literature on the CSP-CFP relationship. Many researchers report a positive (Waddock and Graves 1997; Orlitzky et al. 2003; Van Beurden and Gössling 2008; Ameer and Othman 2012; Lourenço et al. 2012; Saeidi et al. 2015), negative, insignificant (Ullmann 1985) or having a U-shaped (Barnett and Salomon 2012) relationship. Though most of the authors indicate positive findings, the intensity and direction of this relationship is still questionable (Marom 2006). Researchers have revealed that independent dimensions of sustainability impact the CFP differently. Lu and Taylor (2015) found that compared to social sustainability, environmental sustainability contributes more to the CSP-CFP relationship. The relation between performance on social dimension and CFP was reported to be relatively weak by Ullmann (1985).

The positive direction of CSP-CFP relation can be attributed to stakeholder theory (Freeman 2010) that posits the benefits of higher CSP as improved employee morale, reduced legal and compliance cost, higher productivity etc. whereas the negative direction can be attributed to classical shareholder theory (Friedman 1962) which postulates that CSP investment costs have a detrimental impact on firm profits. Lourenço et al. (2012) reinforced the positive direction of CSP-CFP and established that investors in the market penalize firms having substantial profitability but a relatively lower level of CSP. Lu and Taylor (2015) found that a firm's performance on sustainability dimensions improves its financial performance in the long run. They also suggested that environmental sustainability contributes to this positive relation more compared to social sustainability. Ameer and Othman (2012) posited that focus on social aspects increases the profitability while that on environmental issues increases the costs. Some scholars have reported this relationship to be affected by mediating variables like firm-size (Vitezić et al. 2012), research measures (Van Beurden and Gössling 2008), and moderated by financial slack and international diversification (Duque-Grisales and AguileraCaracuel 2019). Tuppura et al. (2016) couldn't find any conclusive answer to the causal 
relation of CSP-CFP in their empirical research conducted for four industries in the USA.

Quazi and Richardson (2012) attributed the variation in results to misspecification of models, the inclusion of confounding factors, and lack of clarity on CSP and CFP variables. They also revealed that most CSP-CFP studies have used regression models, correlation analysis, or t-tests showing that this relationship has a time effect, and more recent studies on CSP-CFP have higher interpretation value. Ullmann (1985) highlighted that the inconsistent relation of CSP-CFP can be attributed to variation in factors like sample size, industrial context, measurement systems used, research methodologies, and methods of data collection and analysis.

Sample characteristics also play an essential role in this relationship with different directions found in the US versus other countries ( $\mathrm{Lu}$ and Taylor 2015). A taxonomy of literature on the CSP-CFP relationship presented by Goyal et al. (2013) revealed that results differ across cultures and economic contexts with no established universal direction for this relationship. Scholars have also verified this relationship in developing countries. Saeidi et al. 2015 showed that in Iran, CSR has a positive effect on CFP mediated through three associate variables. Mishra and Suar (2010) evaluated the influence of CSR on CFP measured by both financial and non-financial variables and concluded that firms having their stock listed show higher CFP than firms without listing. In the Indian context, various researchers have used a different sample and CSPCFP measures to report varying results with the relationship to be positive (Chelawat and Trivedi 2016; Dalal and Thaker 2019), negative (Duque-Grisales and AguileraCaracuel 2019), positive or negative depending on sustainability dimension (Buallay 2019), U-shaped (Sung Kim and Oh 2019), insignificant (Aggarwal 2013), or having a weak association (Ionescu et al. 2019).

Based on the above, we can ascertain that we don't have conclusive evidence of the causality direction and association of CSP-CFP relationship in the Indian context. Hence, we propose the following hypotheses aligned with existing literature on stakeholder theory with CSP measured as ESG parameters covering both aggregate and individual dimensions of environment, society, and governance for CSP.

H1: CSP (ESG) has a positive impact on CFP.

H1A: Environment performance (E) has a positive influence on CFP.

H1B: Social performance (S) has a positive influence on CFP.

H1C: Governance $(G)$ has a positive influence on CFP.

\section{CSP-CFP reverse causal linkage}

The causal direction of the CSP-CFP link is not conclusive. Whether higher CSP leads to revenue growth or better CFP enables capabilities to perform activities towards sustainability dimensions (Wang and Gao 2016) is still an open question. Different theories explain this relationship, but specifically, the instrumental or good management theory (Donaldson and Preston 1995) suggests that CSP influences CFP. In contrast, the slack resources hypothesis (Waddock and Graves 1997) indicate that CFP affects CSP by virtue of creating slack for firms that can be deployed for CSP related activities and allow the firms to seek new solutions to sustainable corporate development (Bansal 
2005). Organizational slack can be defined as "potentially utilizable resources that can be diverted or redeployed to achieve the firm's goals". These set of resources in a firm provide an opportunity to invest in initiatives that can't provide immediate returns (Bansal 2005) or is not a current priority (Melo 2012). The slack resources hypothesis that proposes that CSP being contingent upon prior CFP, has been the least researched in the CSP-CFP link studies (Melo 2012). CSP-CFP link was established to be significant to run in both directions by Waddock and Graves (1997), showing the existence of a virtuous cycle (Surroca et al. 2010). Vitezić et al. (2012) focussed on the reverse causal analysis of CSP-CFP linkage. They used a sample of firms, almost half of which reported on CSR and half didn't and were able to establish that companies having higher CFP and larger size increases the willingness to engage in CSR activities. They also showed that the profitability of such organizations increases the probability of CSR disclosure. Buallay (2019) investigated the causal relationship between ESG and firm performance for the banking sector and reported inconclusive results for the causality of this link. Thus, we need to investigate the reverse causality of the CSP-CFP link, which brings us to our second hypothesis as below.

$\mathrm{H} 2$ : CFP is positively related to CSP.

\section{CSP across industries}

From the sustainability perspective, certain firms fall into specific categories known as controversial industries (CI) or Environmental sensitive industries (ESI). An industry or a firm in Cls or ESIs are inherently controversial either because of their products or because of the process they adopt to achieve their business objectives, which may have an impact on the environment and society. Firms in such industries are regularly confronted on legitimacy because of the prevalent industry practices violating the expectations and welfares of social stakeholders (Du and Vieira 2012). We are treating all these firms in the category of ESI and defined them as per the CPCB (Central Pollution Control Board, Government of India) definitions (See methodology).

Some examples of ESI are petroleum, oil and gas, steel, chemical, pharmaceutical, tobacco-based industries because of the significant impact they have on the environment or society. Such firms are susceptible to more stakeholder scrutiny and hence are found to be engaged more with CSR activities as compared to firms in other industries. This helps them to enhance their reputation (Kilian and Hennigs 2014) and obtain legitimacy (Du and Vieira 2012). Fallah and Mojarrad (2019) researched a sample of 104 firms in ESI and concluded that these firms required to focus more on CSR activities because of higher exposure to environmental or social issues. Rodrigo et al. (2016) analyzed the CSP-CFP relationship focused on five ESI sectors in six Latin American countries and found a negative bidirectional association relationship for the sample data. Hence, there is an additional need to study ESIs independently, as their approach to CSP may differ from non-ESI firms, and a different behavior may be expected for CSPCFP relationships. Based on this, we are proposing the following hypothesis:

H3: CSP is different across ESI and non-ESI industries.

\section{Research design and methodology \\ Data collection}

This study used the sample data of the top 500 Indian firms based on the S\&P BSE 500 index, a free-float weighted index representing $\sim 93 \%$ of total market capitalization 
encapsulating 20 primary industries of the economy. ESG scores, financial and firmspecific data has been collected from Bloomberg as well as Prowess database. Bloomberg database provides annual ESG disclosure scores ranging from 0.1 to 100 on ESG, E, S, and $G$ attributes for firms evaluated on $~ 800$ indicators (Bloomberg Disclosure Score 2019) covering 11,500 unique companies across 83 countries (ESG Data 2019). These scores are based on the public information derived from CSR reports, sustainability reports, annual reports, company websites and other information including the information received through company direct contact (Huber et al. 2017). The Prowess database comprises of the data related to the economic performance of Indian firms managed by CMIE (Centre for Monitoring Indian Economy). This database contains information on all companies in India and is constructed based on the company filings, audited annual reports, and filings to the Ministry of Company Affairs, Government of India.

Sample data was collected for 11 years (2008-2018) consisting of 5500 firm-year observations, since Bloomberg provided consistent data for these years only. Post aggregations, missing observations were found for S-score (200 cases), E-Score (110 cases), ROA (69 cases) and other variables (4 cases) that were removed from the sample resulting in the final set of unbalanced short panel data (11 periods, 284 cross-sections) of 2001 firm-year observations. Panel data has been considered so that we can capture any variation in time and cross-section using a constant or random variable. Sector related information for each firm was considered based on the 2-digit NIC (National Industries Classification) Code (NIC 2008 Codes 2019). We combined a few sectors at a logical level to arrive at the final list of 20 industries. The details of industries with corresponding NIC codes are shown in Table 1. Sample data was divided between firms belonging to ESI or non-ESI for sectoral analysis based on 2-digit NIC code and the classification provided by CРCB in Red, Orange, Green, and White category (CPCB 2019). We considered industries in Red and Orange categories as ESI sectors, whereas those in the Green and White categories were considered as non-ESI ones. Details of this classification are shown in Table 2.

\section{Data analysis}

All statistical analysis was done using EViews 11. Descriptive analysis and correlation for all variables were conducted and analyzed. CSP data were analyzed using t-test and ANOVA to find out a significant difference between ESI and the non-ESI sector. As this is a panel data, we needed to first check for the best regression estimator among pooled, Fixed Effect (FE), and Random Effect (RE) regression. We conducted the Breush-Pagan LM test (for Pooled vs. RE), Likelihood Ratio test (for Pooled vs. FE) and Hausman test (for FE vs. RE), to choose the best estimator. Both LM test and Likelihood Ratio test rejected the hypothesis hence we opted for the Hausman test. Hausman test established that the FE estimator is the most effective for all hypotheses. FE estimator has also been used in multiple other CSP-CFP studies based on similar criteria (Oikonomou et al. 2012; Atan et al. 2018; Landi and Sciarelli 2019; Sung Kim and Oh 2019). Hence, we used FE estimator while running the regression for all models.

In addition to panel regression, we used Granger Causality (GC) test to confirm the bidirectional causal linkage between CSP and CFP. GC test (Granger 1969), predicts the Granger causality of a variable (say Y), by another variable (say X) based on lagged 
Table 1 Details of Industry distribution based on NIC-2008 codes

\begin{tabular}{lllll}
\hline S. No. & Sector & Sub-Sectors & Number of firms & Percentage of Firms \\
\hline 1 & Electricity & 1 & 9 & $1.8 \%$ \\
2 & Transport & 3 & 8 & $1.6 \%$ \\
3 & Civil and Construction & 2 & 27 & $5.4 \%$ \\
4 & Trading & 2 & 29 & $5.8 \%$ \\
5 & Finance & 3 & 94 & $18.8 \%$ \\
6 & Software Services & 2 & 20 & $4.0 \%$ \\
7 & Telecommunication & 1 & 8 & $1.6 \%$ \\
8 & Allied Services & 9 & 33 & $6.6 \%$ \\
9 & Media & 3 & 9 & $1.8 \%$ \\
10 & R\&D and Consultancy & 3 & 8 & $1.6 \%$ \\
11 & Food and Beverages Manufacturing & 3 & 19 & $3.8 \%$ \\
12 & Apparels manufacturing & 3 & 12 & $2.4 \%$ \\
13 & Chemicals and Plastics manufacturing & 2 & 61 & $12.2 \%$ \\
14 & Pharmaceuticals manufacturing & 1 & 32 & $6.4 \%$ \\
15 & Metals and non-Metals Manufacturing & 3 & 46 & $9.2 \%$ \\
16 & Computer and Electricals manufacturing & 2 & 19 & $3.8 \%$ \\
17 & Machinery manufacturing & 1 & 19 & $3.8 \%$ \\
18 & Automobile manufacturing & 2 & 21 & $4.2 \%$ \\
19 & Allied Manufacturing & 4 & 18 & $3.6 \%$ \\
20 & Coke and Refinery manufacturing & 1 & 8 & $1.6 \%$ \\
\hline
\end{tabular}

variables of both $\mathrm{X}$ and $\mathrm{Y}$, rather than the historical values of $\mathrm{Y}$ alone. GC is generally used for testing causality between two or more time-series variables (Babu 2018; Malhotra 2019; Oumarou and Maiga 2019; Petrovska 2019), and has been used to validate causality among variables of panel data also (Cheon and An 2017; Sözen and Tufaner 2019; Kónya 2006; Emirmahmutoglu et al. 2016). Various steps in GC tests were adopted viz. checking the variables stationarity (Augmented Dickey-Fuller Test), checking for cointegration among the variables (Johansen cointegration test), estimating a VAR (Vector Auto Regression) or VECM (Vector Error Correction Model) based on the results from cointegration test, identifying the optimal lag length based on Akaike Information Criteria (AIC) or Schwarz Information Criteria (SIC) and running the pairwise GC test for the set of variables using optimal lag length.

\section{Dependent and independent variables}

CSP and CFP are used as dependent and independent variables interchangeably based on the model. CFP is a dependent variable for Model I to IV whereas CSP is for Model V to VII. As CSP can be measured through different forms like

Table 2 Details of ESI and non-ESI sectors

\begin{tabular}{llllll}
\hline Classification of sectors & Green & Orange & Red & White & Total \\
\hline ESI & N/A & 10 & 12 & N/A & 22 \\
non-ESI & 9 & N/A & N/A & 20 & 29 \\
Total & $\mathbf{9}$ & $\mathbf{1 0}$ & $\mathbf{1 2}$ & $\mathbf{2 0}$ & $\mathbf{5 1}$ \\
\hline
\end{tabular}


reputation rating, other externally visible measures, disclosures and perceptual measures (Grewatsch and Kleindienst 2017), we have used Bloomberg scores, an external measure as a proxy for measuring CSP. The scores are obtained for environmental, social and corporate governance aspects of sustainability. Using ESG scores as a proxy for measuring CSP is consistent with many CSP-CFP studies (Aggarwal 2013; Tyagi and Sharma 2013; Chelawat and Trivedi 2016; Atan et al. 2018; Tamimi and Sebastianelli 2017; Landi and Sciarelli 2019; Sung Kim and Oh 2019).

CFP is also a multidimensional construct generally classified as accounting-based (accounting returns), market-based (investor returns), and perceptual (reputational rankings) measures (Orlitzky et al. 2003; Grewatsch and Kleindienst 2017). Accounting measures are based on short-term historical performance (Baird et al. 2012) reflecting the past (Grewatsch and Kleindienst 2017) and focus on firm earnings based on managerial decisions (Orlitzky et al. 2003). Market measures reflect the long-term future aligned with investor expectations (Grewatsch and Kleindienst 2017) and are not prone to different accounting methods. Research using accounting-based measures establish a stronger CSP-CFP linkage and are highly correlated with CSP as compared to marketing-based measures (Grewatsch and Kleindienst 2017; Orlitzky et al. 2003; Lu and Taylor 2015). Including both market and accounting-based measures simultaneously in a CSP-CFP study helps to evaluate historical as well as future CFP of the firm (Atan et al. 2018) and evades any possible distortion because of operational and accounting policy choices (Gregory and Whittaker 2013).

We have considered ROA (Return on Assets) as accounting-based and ROE (Return on Equity) and Tobin'sQ as market-based measures of CFP. ROA measures the effectiveness of a firm producing profits by exploiting its internal assets. ROE, on the other hand, measures how companies manage their capital to produce profits. Tobin'sQ is unique in capturing the shareholder value since it captures both valuation and performance from the value creation perspective in the longterm (Hillman and Keim 2001; Peng and Yang 2014). These measures have been used in multiple studies for measuring CFP (Hull and Rothenberg 2008; Saeidi et al. 2015; Vitezić et al. 2012; Lourenço et al. 2014; Atan et al. 2018; Peng and Yang 2014; Ameer and Othman 2012; Barnett and Saloman, 2012; Berman et al. 1999; Legendre and Coderre 2013). Tobin'sQ is also used in multiple studies to capture the value creation aspect of a firm (Chakrabarty and Wang 2012; Bajic and Yurtoglu 2018; Surroca et al. 2010; Atan et al. 2018; Yu and Zhao 2015; Lee and Pati 2012; Chelawat and Trivedi 2016; Buallay 2019).

\section{Control variables}

CSP-CFP relationship is influenced by a lot of contextual aspects (Peloza 2009). Dienes et al. 2016, reported that firm size, firm age, and profitability are the most prominent variables used in sustainability studies. Firm size, sector, risk, and R\&D intensity are the best control variables while evaluating the CSP-CFP relationship (Andersen and Dejoy 2011) and have been used in multiple CSP-CFP studies (Waddock and Graves 1997, Orlitzky et al. 2003; Ullmann 1985; Barnett and Salomon 2012; Artiach et al. 2010; Zahid and Ghazali 2017; Bhatia and Tuli 2017; Bajic and Yurtoglu 2018; Mishra and Suar 2010). CSP-CFP effect is moderated by innovation, which is a significant driver of 
CFP (McWilliams and Siegel 2001) and an essential element of sustainability-focused strategy (Placet et al. 2005). R\&D intensity (Chakrabarty and Wang 2012) is a key factor since sustainability issues can be handled through solutions based on innovation (Porter and Van der Linde 1995) and is one way of measuring the innovation in a firm, hence it has been considered as one of the control variables in this study.

The systematic risk for a firm is a critical factor for sustainability that impacts both CSP and CFP in different ways. As the focus on environmental and social issues increases, firms need to adopt risk management practices and monitor it as an important factor (Wong 2014). Hence, risk operationalized as the beta of the firm has been considered in this study. CSP-CFP relationship is conditioned on firms' industry-specific context and its unique capabilities (Baird et al. 2012), and hence it is inevitable to conduct an industry-wide analysis. Firm-age is operationalized as "the number of years passed from the year of incorporation" for a particular year into consideration and Firm-size is operationalized as market-capitalization for the firm. The operationalization of all variables is presented in Table 3.

\section{Estimation models}

We have used the following estimation models for testing hypotheses H1, H1A, H1B, and $\mathrm{H} 1 \mathrm{C}$ :

\section{Model I to IV}

$$
\text { CFPijt }=C+\beta 1 * \text { CSPkjt }+\beta 2 * \text { FAgejt }+\beta 3 * \text { Fsizejt }+\beta 4 * \text { RnDjt }+\beta 5 * \text { Riskjt }+\varepsilon j t
$$

$\mathrm{H} 2$ has been tested using the following models:

\section{Model V to VII}

$$
\text { CSPkjt }=C+\beta 1 * \text { CFPijt }+\beta 2 * \text { FAgejt }+\beta 3 * \text { Fsizejt }+\beta 4 * \text { RnDjt }+\beta 5 * \text { Riskjt }+\varepsilon j t
$$

\section{Models for the GC test}

The following models have been used for validating the bidirectional causality between CSP and CFP.

$$
\begin{aligned}
& \text { CFPijt }=\mathrm{C}+\sum_{l=1}^{l} \alpha \mathrm{lCFPij}(\mathrm{t}-\mathrm{l})+\sum_{l=1}^{l} \gamma \mathrm{lCSPkj}(\mathrm{t}-\mathrm{l})+\varepsilon \mathrm{jt} \\
& \text { CSPkjt }=\mathrm{C}+\sum_{l=1}^{l} \alpha \mathrm{lCSP} \mathrm{kj}(\mathrm{t}-\mathrm{l})+\sum_{l=1}^{l} \gamma \mathrm{lCFPij}(\mathrm{t}-\mathrm{l})+\varepsilon \mathrm{jt}
\end{aligned}
$$

Here $\mathrm{i}=1,2$ and 3 so that $\mathrm{CFP}_{1}$ is $\mathrm{ROA}, \mathrm{CFP}_{2}$ is $\mathrm{ROE}$, and $\mathrm{CFP}_{3}$ is Tobin's $\mathrm{Q}$. CFPijt represents CFP for firm $\mathrm{j}$ in time-period $\mathrm{t}$. Also, $\mathrm{k}=1,2,3$, and 4 so that $\mathrm{CSP}_{1}$ to $\mathrm{CSP}_{4}$ measures ESGjt, Ejt, Sjt, and Ejt representing the CSP measured as ESG-score, E-score, S-score, and G-score respectively for firm $j$ in time-period t. C is the intercept and 1 indicates the lag orders. FAgejt, Fsizejt, RnDjt, and Riskjt represent firm-age, firm-size, $R \& D$ Intensity and systematic risk for firm $j$ in timeperiod t. $\varepsilon_{\mathrm{jt}}$ represents the error term. 
Table 3 Operationalization of variables

\begin{tabular}{|c|c|c|c|c|c|}
\hline Variable & Name & Mnemonic & Type & Operationalization & Source \\
\hline \multirow[t]{3}{*}{ CFP } & $\begin{array}{l}\text { Return } \\
\text { on } \\
\text { Assets }\end{array}$ & $\mathrm{ROA}$ & Ratio & $\begin{array}{l}\text { Indicator of how profitable a company is } \\
\text { relative to its total assets, in percentage } \\
\text { calculated as (Trailing } 12 \mathrm{M} \text { Net Income / } \\
\text { Average Total Assets) * } 100\end{array}$ & Bloomberg \\
\hline & $\begin{array}{l}\text { Return } \\
\text { on } \\
\text { Equity }\end{array}$ & $\mathrm{ROE}$ & Ratio & $\begin{array}{l}\text { Measure of a corporation's profitability } \\
\text { calculated as: (T12 Net Income Available for } \\
\text { Common Shareholders / Average Total } \\
\text { Common Equity) }{ }^{*} 100\end{array}$ & Bloomberg \\
\hline & $\begin{array}{l}\text { Tobin's } \\
\text { Q }\end{array}$ & TobinsQ & Ratio & $\begin{array}{l}\text { Ratio of the market value of a firm to the } \\
\text { replacement cost of the firm's assets } \\
\text { calculated as (Market Cap + Total Liabilities + } \\
\text { Preferred Equity + Minority Interest) / Total } \\
\text { Assets }\end{array}$ & Bloomberg \\
\hline \multirow[t]{4}{*}{ CSP } & $\begin{array}{l}\text { ESG- } \\
\text { Score }\end{array}$ & ESG & Numeric & $\begin{array}{l}\text { Proprietary Bloomberg score ranging from } 0.1 \\
\text { to } 100 \text { based on the extent of a company's } \\
\text { Environmental, Social, and Governance (ESG) } \\
\text { disclosure. }\end{array}$ & Bloomberg \\
\hline & E-Score & E & Numeric & $\begin{array}{l}\text { Proprietary Bloomberg score ranging from } 0.1 \\
\text { to } 100 \text { based on the extent of a company's } \\
\text { environmental disclosure as part of } \\
\text { Environmental, Social and Governance (ESG) } \\
\text { data. }\end{array}$ & Bloomberg \\
\hline & S-Score & S & Numeric & $\begin{array}{l}\text { Proprietary Bloomberg score ranging from } 0.1 \\
\text { to } 100 \text { based on the extent of a company's } \\
\text { social disclosure as part of Environmental, } \\
\text { Social and Governance (ESG) data. }\end{array}$ & Bloomberg \\
\hline & G-Score & G & Numeric & $\begin{array}{l}\text { Proprietary Bloomberg score ranging from } 0.1 \\
\text { to } 100 \text { based on the extent of a company's } \\
\text { governance disclosure as part of } \\
\text { Environmental, Social and Governance (ESG) } \\
\text { data. }\end{array}$ & Bloomberg \\
\hline \multirow[t]{6}{*}{ Control Variables } & $\begin{array}{l}\text { Firm } \\
\text { Size }\end{array}$ & Fsize & Numeric & Log of Market Capitalization & Prowess \\
\hline & Sector & Sector & Category & $\begin{array}{l}\text { Sector defined on the basis of National } \\
\text { Industry Classification 2-Digit Code }\end{array}$ & Prowess \\
\hline & $\begin{array}{l}\text { Firm } \\
\text { Age }\end{array}$ & Fage & Numeric & $\begin{array}{l}\text { Difference between the current year from Year } \\
\text { of incorporation }\end{array}$ & Prowess \\
\hline & $\begin{array}{l}\text { R\&D } \\
\text { Intensity }\end{array}$ & R_D & Ratio & $\begin{array}{l}\text { R\&D expenditure as a \% of revenue calculated } \\
\text { as (R\&D Expense / Revenue) }{ }^{*} 100\end{array}$ & Bloomberg \\
\hline & Risk & Risk & Numeric & $\begin{array}{l}\text { Volatility measure of the percentage price } \\
\text { change of the security given a } 1 \% \text { change in } \\
\text { a representative market index. The beta value } \\
\text { is considered as risk }\end{array}$ & Prowess \\
\hline & ESI & ESI & Binary & $\begin{array}{l}1 \text { for firms belonging to ESI sector and } 0 \\
\text { otherwise based on categorization done by } \\
\text { Central Pollution Control Board, Government } \\
\text { of India }\end{array}$ & Prowess \\
\hline
\end{tabular}

\section{Findings}

\section{Descriptive analysis and correlations}

We have reported the descriptive statistics for all variables in Table 4. All CSP variables have positive skewness (long right tail) and Kurtosis (Leptokurtic), and negligible $p$-value for Jarque-Bera test supporting the non-normal nature of the data. For the CSP variables, we observe that the mean disclosure scores are highest for $\mathrm{G}$, followed by $\mathrm{S}$ and $\mathrm{E}$ with standarddeviation of G (7.488) much less compared to E(14.16), S(15.83) and ESG(11.72) revealing that G Scores are least spread. The trend analysis (see Fig. 1) of CSP scores along the years reveals 


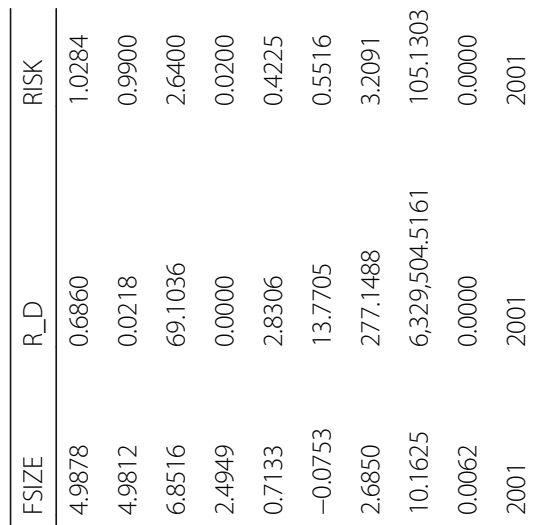

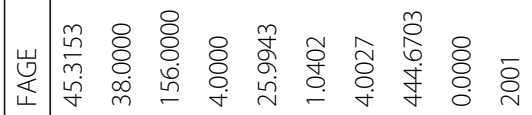

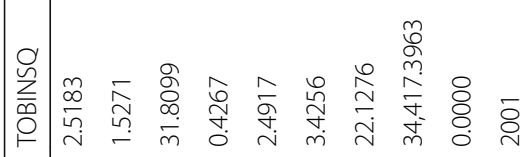

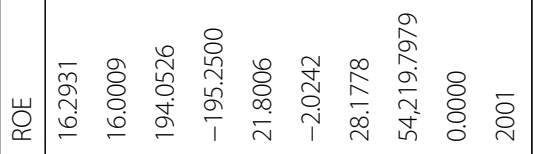

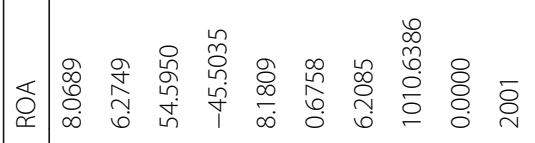

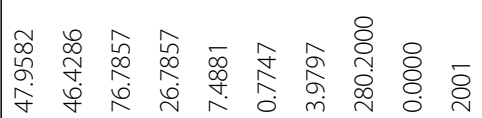

$\checkmark$



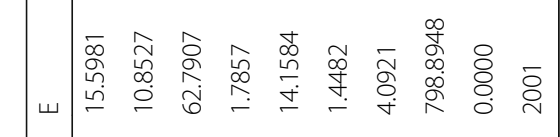




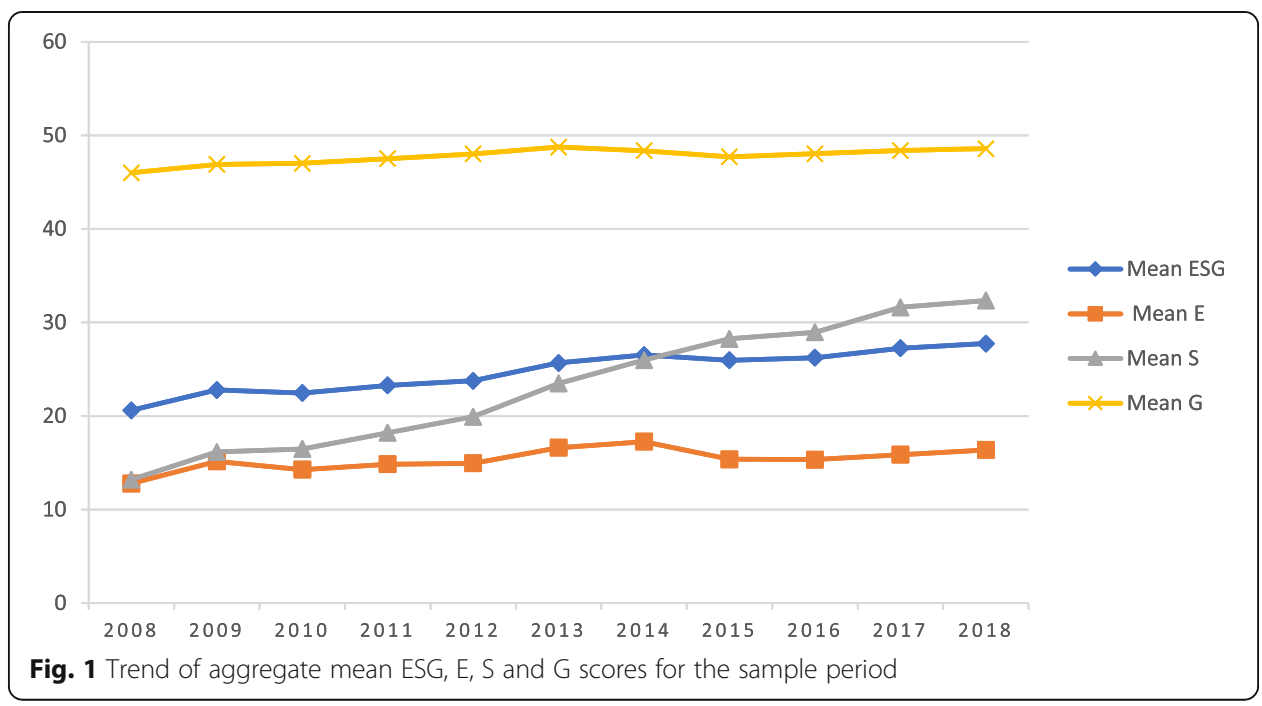

a continuously increasing trend for ESG and S scores in the sample period whereas E and G scores are stagnant around their mean values. This means that Indian firms are making improvements in coverage of sustainability attributes aligned along the social dimension, but the environmental and governance aspect is not changing to a more considerable extent.

The mean value of Tobin'sQ suggests that most Indian firms are valued double than their intrinsic value, which suggests the health status of the Indian corporates. Average firm-age of 45 years reflects that most of the firms currently present in the sample are among the firms established after independence. A low average value of R\&D intensity suggests that most Indian firms have a lesser focus on the R\&D activities, which is reflected by the minimum (0) and maximum (69.10) having a median at 0.02 . The mean risk value of 1.02 may be interpreted in two ways. First, the sample data represents most of the Indian firms, and hence the average is around 1 aligned with market risk. Second, Indian firms are not much risky, and volatility is low for Indian firms. The median value around 1 also reflects the fact that the spread of firms around beta averages out the overall risk as the sample covers more than $93 \%$ of the free-float market. We have reported the correlations among all variables in Table 5 . There is a significant correlation between CSP and CFP variables mostly at 0.01 significant level. Firm-age, firm-size and risk are also correlated with most of the other variables. Correlation among different CSP and CFP variables doesn't show a consistent and significant direction.

\section{Causality between CSP to CFP and vice-versa}

The first step for the GC test is to verify the stationarity of variables. We deployed various unit root tests like Levin, Lin \& Chu, Im, Pesaran and Shin W-stat, ADF - Fisher Chisquare, and PP - Fisher Chi-square for all variables of CSP and CFP. The null hypothesis for all these tests is that the variable has a unit-root i.e., the series is non-stationary. The results of these tests are shown in Table 6 and indicate that the data series for all variables are stationary at level. The second step in the GC test is to validate whether the variables are co-integrated or not. Since all variables are stationary at level i.e. I(0), no long-term relationship exists between the variables, and hence there is no need for estimating for 


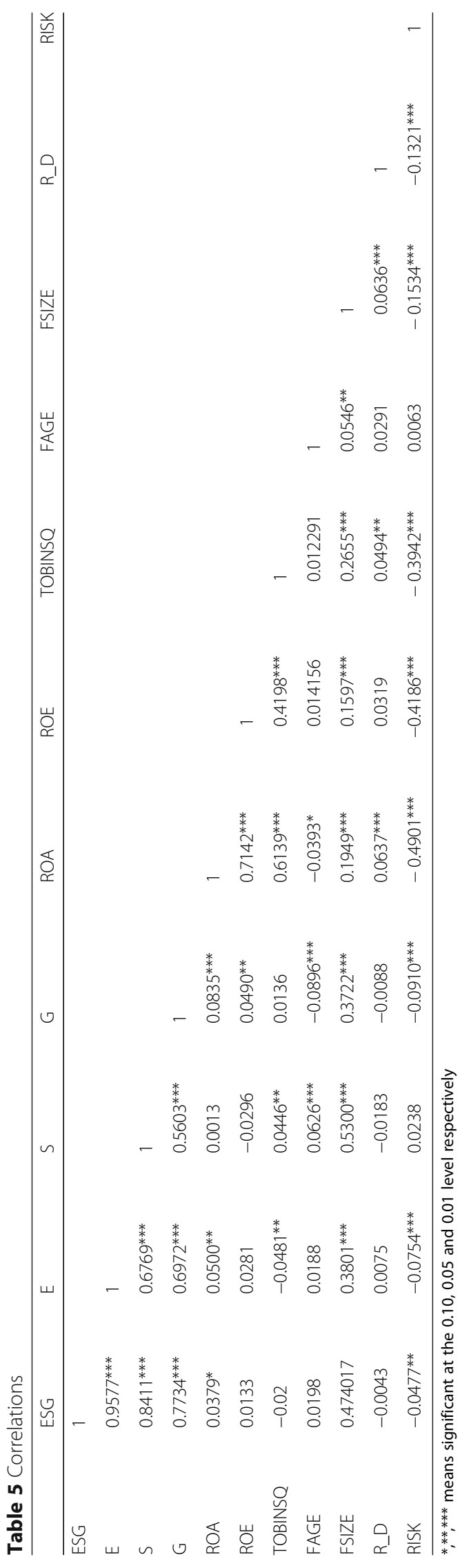


Table 6 Test of stationarity at Level

\begin{tabular}{lllll}
\hline & $p$-values & & \\
\cline { 2 - 5 } & Levin, Lin \& Chu & $I m$, Pasaran and Shin W-Stat & ADF-Fisher Chi-square & PP-Fisher Chi-Square \\
\hline ROA & 0.0000 & 0.0000 & 0.0000 & 0.0000 \\
ROE & 0.0000 & 0.0000 & 0.0000 & 0.0000 \\
Tobins'Q & 0.0000 & 0.0000 & 0.0000 & 0.0000 \\
ESG & 0.0000 & 0.0000 & 0.0000 & 0.0000 \\
E & 0.0000 & 0.0034 & 0.0072 & 0.0103 \\
S & 0.0000 & 0.0081 & 0.2395 & 0.0014 \\
G & 0.0000 & 0.0001 & 0.0033 & 0.0010 \\
\hline
\end{tabular}

cointegration. Hence, we didn't run any cointegration test and concluded that we must apply the VAR model with appropriate lag length. The third step in the GC test is to identify the appropriate lag length to be used in the VAR model. We identified different laglengths as 1, 2, 3 and 9 for different pairs of CSP and CFP based on AIC and SIC, which was used appropriately in corresponding models while running the GC test.

The final step in this process was to conduct the pair-wise GC test for assessing the causality between the variables. The null hypothesis for GC is that there is no Granger causality from one variable to another. If the $p$-value is significant at the 0.05 level, then we reject the null hypothesis and conclude that causality exists from one variable to another. Eviews provides two types of GC for panel data viz. "Stacked test with common coefficients" which assumes that all coefficients are the same across all cross-sections, and "Dumitrescu-Hurlin with individual coefficients" which assumes that all coefficients are different across crosssections. We have taken the stacked test method as this is an unbalanced panel data and we are treating the whole set of data as one stacked set rather than having different treatment across cross-sections. The result of pairwise GC test for various variables of CSP and CFP is depicted in Table 7 which shows that none of the null hypothesis could be rejected except that of causality from TobinsQ to $S$ for all firms. For ESI based firms, similar results were found with no causality detected between any variable. For non-ESI firms, bidirectional causality was reported among ROA to ESG and G and unidirectional causality was reported from $\mathrm{E}$ to ROA, ROE to $\mathrm{S}$ and TobinsQ to $\mathrm{S}$. However, the overall findings of Granger causality, don't give a concrete direction for CSP-CFP variables in this context.

\section{Panel Data regression results}

Table 8 shows the results of FE Regression conducted for all models relevant to CSP- > CFP relationship whereas results of CFP- > CSP are depicted in Table 9.

\section{Impact of CSP on CFP}

The results show that for Model-I and Model-II, CSP-ESG and CSP-E influence ROA at 0.10 significant level with a negative coefficient, whereas they are statistically insignificant in influencing the ROE. For Model-3 and Model-4, CSP-S and CSP-G are statistically insignificant in influencing either ROA or ROE, respectively. For all the models, Firm size influences both ROA and ROE at 0.01 significant level with a positive coefficient. Similarly, risk impacts ROA at 0.01 significant level for both Model-I and II and at 0.05 levels for Model-III and IV with positive coefficients. However, it affects ROE at 0.01 significant level for all 
Table 7 Granger Causality test results for CSP-CFP relationship (All Firms)

\begin{tabular}{|c|c|c|c|c|c|c|}
\hline \multirow{2}{*}{$\begin{array}{l}\text { Pairwise causality } \\
\text { Null Hypothesis }\end{array}$} & \multicolumn{2}{|c|}{ All Firms } & \multicolumn{2}{|c|}{ ESI Firms } & \multicolumn{2}{|c|}{ Non-ESI Firms } \\
\hline & F-stat & p-value & F-stat & $\begin{array}{r}\text { p- } \\
\text { value }\end{array}$ & F-stat & p-value \\
\hline TOBINSQ does not Granger Cause ESG & 0.71531 & 0.6943 & 0.27347 & 0.8446 & 0.22019 & 0.8025 \\
\hline ESG does not Granger Cause TOBINSQ & 0.84269 & 0.5780 & 1.33747 & 0.2609 & 0.77825 & 0.4598 \\
\hline TOBINSQ does not Granger Cause E & 0.17298 & 0.9965 & 0.47942 & 0.6967 & 0.20293 & 0.8164 \\
\hline E does not Granger Cause TOBINSQ & 0.69168 & 0.7157 & 0.68757 & 0.5598 & 0.60715 & 0.5453 \\
\hline TOBINSQ does not Granger Cause S & 1.97194 & $0.0459 * *$ & 1.81039 & 0.0732 & 3.15215 & $0.0437 * *$ \\
\hline S does not Granger Cause TOBINSQ & 0.81897 & 0.5995 & 0.73198 & 0.6789 & 1.42079 & 0.2426 \\
\hline TOBINSQ does not Granger Cause G & 0.79533 & 0.6211 & 1.23483 & 0.2804 & 0.00314 & 0.9969 \\
\hline G does not Granger Cause TOBINSQ & 0.69175 & 0.7156 & 0.68570 & 0.7206 & 0.21559 & 0.8061 \\
\hline ROE does not Granger Cause ESG & 0.70889 & 0.5467 & 0.33138 & 0.8027 & 6.33378 & $0.0121 * *$ \\
\hline ESG does not Granger Cause ROE & 0.94564 & 0.4178 & 1.13209 & 0.3351 & 1.62107 & 0.2035 \\
\hline ROE does not Granger Cause E & 0.79228 & 0.4982 & 0.50565 & 0.6785 & 3.28574 & 0.0704 \\
\hline E does not Granger Cause ROE & 2.13276 & 0.0944 & 1.93374 & 0.1226 & 2.03062 & 0.1547 \\
\hline ROE does not Granger Cause S & 0.25314 & 0.8591 & 1.51678 & 0.1527 & 2.67312 & 0.1026 \\
\hline S does not Granger Cause ROE & 0.17822 & 0.9112 & 1.28033 & 0.255 & 0.25308 & 0.6151 \\
\hline ROE does not Granger Cause $\mathrm{G}$ & 1.52065 & 0.2074 & 1.18600 & 0.3087 & 9.96105 & $0.0017 * *$ \\
\hline G does not Granger Cause ROE & 1.06357 & 0.3636 & 1.78453 & 0.0814 & 3.72133 & 0.0542 \\
\hline ROA does not Granger Cause $\mathrm{G}$ & 2.07185 & 0.1263 & 0.61683 & 0.6042 & 9.79724 & $0.0018 * *$ \\
\hline G does not Granger Cause ROA & 0.14874 & 0.8618 & 1.38603 & 0.2457 & 6.22572 & $0.0129 * *$ \\
\hline ROA does not Granger Cause ESG & 1.24504 & 0.2647 & 0.24513 & 0.6206 & 2.62520 & 0.1057 \\
\hline ESG does not Granger Cause ROA & 0.00296 & 0.9566 & 2.71626 & 0.0996 & 4.36817 & $0.0371 * *$ \\
\hline ROA does not Granger Cause E & 0.47469 & 0.4909 & 0.17183 & 0.6786 & 0.61169 & 0.4345 \\
\hline E does not Granger Cause ROA & 0.00168 & 0.9673 & 3.66268 & 0.0559 & 4.61094 & $0.0322 * *$ \\
\hline ROA does not Granger Cause $\mathrm{S}$ & 1.22487 & 0.2686 & 0.29680 & 0.586 & 1.97231 & 0.1403 \\
\hline S does not Granger Cause ROA & 0.06088 & 0.8051 & 0.17459 & 0.6761 & 0.03998 & 0.9608 \\
\hline
\end{tabular}

Cells marked in green and with ** means hypothesis rejected and causality among variables

models with negative coefficients. R\&D Intensity is influencing ROA at 0.01 significant level with a negative coefficient for Model-II only and is statistically insignificant for all other models. It is also statistically insignificant for its influence on ROE in all models.

The findings indicate that all CSP measures except CSP-S are significant for all models except Model-III when CFP is measured as Tobin'sQ. CSP-ESG and CSP-G impact Tobin'sQ at 0.05 significant level, whereas CSP-E impacts it at 0.01 significant level with all having negative coefficients. The impact of CSP-S on Tobin's Q is statistically insignificant. Firm age influences Tobin'sQ in Model-I and Model-II at 0.05 significant level and in Model-III and Model-IV at 0.01 significant level with all having a negative coefficient. Firm-size, on the other hand, influences this CFP measure at 0.01 significant level for all models with a positive coefficient. Both R\&D intensity and risk have a statistically insignificant relationship with Tobin'sQ. Based on the above, all of H1, H1A, H1B, or H1C were rejected since the positive relationship between CSP- > CFP could not be established.

\section{Impact of CFP on CSP}

The reverse effect of the CSP-CFP relationship was tested using Model V, VI and VII corresponding to ROA, ROE and TobinsQ as CFP measures. ROA revealed a negative relationship with CSP-ESG and CSP-E at 0.01 significant level, whereas no relationship was established for CSP-S or CSP-G dimension. ROE didn't have any significant relationship with any CSP measure. Tobin'sQ revealed a negative relationship with CSPESG, CSP-E and CSP-G at 0.05, 0.01 and 0.05 significant level respectively whereas no relation was established for CSP-S. The coefficient of firm-age was significantly positive at 0.01 level for all models, whereas firm-size was insignificant for most of the models. 
Table 8 Panel Data (FE) regression model (CSP- > CFP)

\begin{tabular}{|c|c|c|c|c|c|}
\hline Observations N & & 2001 & 2001 & 2001 & 2001 \\
\hline Periods & & 11 & 11 & 11 & 11 \\
\hline Cross-Sections & & 284 & 284 & 284 & 284 \\
\hline Dependent Variable & Label & Model I (ESG) & Model II (E) & Model III (S) & Model IV (G) \\
\hline \multirow[t]{11}{*}{$\mathrm{ROA}$} & C & $8.8137^{* * *}$ & $9.1119^{* * *}$ & $8.0414^{* * *}$ & $10.6819^{* * *}$ \\
\hline & CSP & $-0.0407^{*}$ & $-0.0311^{*}$ & -0.0196 & -0.0372 \\
\hline & FAGE & $-0.6932^{* * *}$ & -0.7123 & $-0.6895^{* * *}$ & $-0.7217^{* * *}$ \\
\hline & FSIZE & $6.0380^{* * *}$ & $6.0378^{* * *}$ & $6.0620^{* * *}$ & $6.0789^{* * *}$ \\
\hline & R_D & -0.0592 & $-0.0586^{* * *}$ & -0.0609 & -0.0545 \\
\hline & RISK & $1.5837^{* * *}$ & $1.5994^{* * *}$ & $1.5290^{* *}$ & $1.5492^{* *}$ \\
\hline & $R^{2}$ & 0.7423 & 0.7423 & 0.7420 & 0.7420 \\
\hline & Adj. $R^{2}$ & 0.6990 & 0.6990 & 0.6987 & 0.6987 \\
\hline & F-statistic & 17.1264 & 17.1249 & 17.1003 & 17.1001 \\
\hline & $p$-value & 0.0000 & 0.0000 & 0.0000 & 0.0000 \\
\hline & DW-stat & 1.5120 & 1.5120 & 1.5083 & 1.5111 \\
\hline \multirow[t]{11}{*}{ ROE } & Constant & $42.3325^{* * *}$ & $42.2195^{* * *}$ & $41.7956^{* * *}$ & $39.9914^{* * *}$ \\
\hline & CSP & 0.0006 & -0.0079 & -0.0070 & 0.0743 \\
\hline & FAGE & $-2.1863^{* * *}$ & $-2.1797^{* * *}$ & $-2.1691^{* * *}$ & $-2.2139^{* * *}$ \\
\hline & FSIZE & $15.7360^{* * *}$ & $15.7227^{* * *}$ & $15.7263^{* * *}$ & $15.7515^{* * *}$ \\
\hline & R_D & -0.1393 & -0.1396 & -0.1406 & -0.1454 \\
\hline & RISK & $-5.2258^{* *}$ & $-5.2087^{* *}$ & $-5.2272^{* *}$ & $-5.2528^{* *}$ \\
\hline & $R^{2}$ & 0.5951 & 0.5952 & 0.5952 & 0.5954 \\
\hline & Adj. $R^{2}$ & 0.5271 & 0.5271 & 0.5271 & 0.5273 \\
\hline & F-statistic & 8.7404 & 8.7406 & 8.7406 & 8.7459 \\
\hline & $p$-value & 0.0000 & 0.0000 & 0.0000 & 0.0000 \\
\hline & DW-stat & 1.8301 & 1.8302 & 1.8301 & 1.8306 \\
\hline \multirow[t]{11}{*}{ Tobin's Q } & Constant & $-6.9274^{* * *}$ & $-6.8780^{* * *}$ & $-6.4816^{* * *}$ & $-6.1930^{* * *}$ \\
\hline & CSP & $-0.0123^{* *}$ & $-0.0126^{* * *}$ & 0.0031 & $-0.0167^{* *}$ \\
\hline & FAGE & $-0.0324^{* *}$ & $-0.0358^{* *}$ & $-0.0526^{* * *}$ & $-0.0389 * * *$ \\
\hline & FSIZE & $2.2471^{* * *}$ & $2.2420^{* * *}$ & $2.2659^{* * *}$ & $2.2583^{* * *}$ \\
\hline & R_D & 0.0012 & 0.0012 & 0.0022 & 0.0030 \\
\hline & RISK & 0.0167 & 0.0279 & 0.0030 & 0.0083 \\
\hline & $R^{2}$ & 0.7970 & 0.7974 & 0.7965 & 0.7970 \\
\hline & Adj. $R^{2}$ & 0.7628 & 0.7633 & 0.7623 & 0.7629 \\
\hline & F-statistic & 23.3376 & 23.3964 & 23.2681 & 23.3416 \\
\hline & $p$-value & 0.0000 & 0.0000 & 0.0000 & 0.0000 \\
\hline & DW-stat & 1.3981 & 1.3999 & 1.3995 & 1.3997 \\
\hline
\end{tabular}

******* Significance at 10,5 and $1 \%$ levels, respectively

Innovation was insignificant for models using CSP-ESG and CSP-E whereas it was significant at 0.05 and 0.10 significant level for CSP-S and CSP-G respectively. Risk was significantly positive at 0.10 and 0.05 level for CSP-ESG and CSP-E, respectively, whereas insignificant for CSP-S and CSP-G. Overall, no definite relationship was established for CFP- > CSP relationship, and some relationship was found to be significantly negative, hence rejecting $\mathrm{H} 2$. 
Table 9 Panel Data (FE) regression model (CFP- > CSP)

\begin{tabular}{|c|c|c|c|c|}
\hline Observations N & & 2001 & 2001 & 2001 \\
\hline Periods & & 11 & 11 & 11 \\
\hline Cross-Sections & & 284 & 284 & 284 \\
\hline Dependent Variable & Label & Model V (ROA) & Model VI (ROE) & Model VII (TobinsQ) \\
\hline \multirow[t]{11}{*}{ ESG } & Constant & $-16.7046^{* * *}$ & $-17.2191^{* * *}$ & $-18.709^{* * *}$ \\
\hline & CFP coefficient & $-0.0537^{*}$ & 0.0001 & $-0.2223^{* *}$ \\
\hline & FAGE & $1.0081^{* * *}$ & $1.0478^{* * *}$ & $1.0376^{* * *}$ \\
\hline & FSIZE & -0.880608 & $-1.2089^{* *}$ & -0.7049 \\
\hline & R_D & -0.042774 & -0.0397 & -0.0393 \\
\hline & RISK & $1.2747^{*}$ & $1.1925^{*}$ & $1.1926^{*}$ \\
\hline & $R^{2}$ & 0.8343 & 0.8339 & 0.8343 \\
\hline & Adj. $R^{2}$ & 0.8064 & 0.8059 & 0.8065 \\
\hline & F-statistic & 29.9207 & 29.8423 & 29.9404 \\
\hline & $\mathrm{p}$-value & 0.0000 & 0.0000 & 0.0000 \\
\hline & DW-stat & 0.8418 & 0.8377 & 0.8377 \\
\hline \multirow[t]{11}{*}{ E } & Constant & $-12.2810^{* * *}$ & $-12.8643^{* * *}$ & $-15.4612^{* * *}$ \\
\hline & CFP coefficient & $-0.0682^{*}$ & -0.0016 & $-0.3769^{* * *}$ \\
\hline & FAGE & $0.7074^{* * *}$ & $0.7542^{* * *}$ & $0.7405^{* * *}$ \\
\hline & FSIZE & -1.1685 & $-1.5594^{* *}$ & -0.7314 \\
\hline & R_D & -0.0382 & -0.0345 & -0.0337 \\
\hline & RISK & $2.1680^{* *}$ & $2.0541^{* *}$ & $2.0630^{* *}$ \\
\hline & $R^{2}$ & 0.8112 & 0.8108 & 0.8117 \\
\hline & Adj. $R^{2}$ & 0.779474 & 0.7790 & 0.7801 \\
\hline & F-statistic & 25.5459 & 25.4794 & 25.6285 \\
\hline & $p$-value & 0.0000 & 0.0000 & 0.0000 \\
\hline & DW-stat & 0.8278 & 0.8237 & 0.8255 \\
\hline \multirow[t]{11}{*}{ S } & Constant & $-74.7562^{* * *}$ & $-75.1955^{* * *}$ & $-74.4829^{* * *}$ \\
\hline & CFP coefficient & -0.0539 & -0.0017 & 0.1170 \\
\hline & FAGE & $2.3296^{* * *}$ & $2.3655^{* * *}$ & $2.3746^{* * *}$ \\
\hline & FSIZE & -0.9572 & -1.2579 & $-1.5498^{*}$ \\
\hline & R_D & $-0.1746^{* *}$ & $-0.1718^{* *}$ & $-0.1717^{* *}$ \\
\hline & RISK & -0.2346 & -0.3263 & -0.3175 \\
\hline & $R^{2}$ & 0.8105 & 0.8103 & 0.8104 \\
\hline & Adj. $R^{2}$ & 0.7786 & 0.7784 & 0.7785 \\
\hline & F-statistic & 25.4279 & 25.3951 & 25.4061 \\
\hline & $p$-value & 0.0000 & 0.0000 & 0.0000 \\
\hline & DW-stat & 0.9156 & 0.9151 & 0.9166 \\
\hline \multirow[t]{8}{*}{ G } & Constant & $31.6267^{* * *}$ & $31.1452^{* * *}$ & $30.2018^{* * *}$ \\
\hline & ROA/ROE/TobinsQ & -0.0282 & 0.0050 & $-0.1723^{* *}$ \\
\hline & FAGE & $0.3600^{* * *}$ & $0.3917^{* * *}$ & $0.3729^{* * *}$ \\
\hline & FSIZE & -0.0478 & -0.298613 & 0.1705 \\
\hline & R_D & $0.0798^{*}$ & $0.0821^{*}$ & $0.0817^{*}$ \\
\hline & RISK & 0.4172 & 0.4003 & 0.3743 \\
\hline & $R^{2}$ & 0.7672 & 0.7671 & 0.7676 \\
\hline & Adj. $R^{2}$ & 0.7281 & 0.7279 & 0.7286 \\
\hline
\end{tabular}


Table 9 Panel Data (FE) regression model (CFP- > CSP) (Continued)

\begin{tabular}{lllll}
\hline Observations N & & 2001 & 2001 & 2001 \\
\hline & F-statistic & 19.5918 & 19.5746 & 19.6384 \\
& p-value & 0.0000 & 0.0000 & 0.0000 \\
& DW-stat & 1.0735 & 1.0707 & 1.0719 \\
\hline
\end{tabular}

$* * * * * *$ Significance at 10,5 and $1 \%$ levels, respectively

\section{Sectoral analysis}

ESG, E, S, and G scores were aggregated sector-wise and a snapshot of mean ESG, E, S and $G$ scores for various sectors reveal that, though the scores may be diverse for different sectors, they move in the same direction (Refer Fig. 2). For all sectors, G-scores are highest followed by $\mathrm{S}$ and E-scores. This shows that Indian firms mostly focus on governance, followed by the social and environmental dimensions of sustainability across all sectors. We can observe that sector 6 (Software Services) is an outlier in terms of their performance on ESG dimensions, whereas sector-9 (Media) is at the lowest strata followed by sector-2 (Transport), and sector-10 (R\&D and Consultancy). It is also interesting to observe that sector-20 (Coke and Refinery) and sector-18 (Automobile) are the next best performers with a focus on their social and environmental efforts. This may be because these firms may be investing in improving their perception along these dimensions of sustainability.

Kruskal Wallis test for difference among sectors shows a statistically significant difference across all dimensions viz. $\mathrm{ESG}\left(\mathrm{X}^{2}=260.894, \mathrm{df}=19, p=0.0000\right), \mathrm{E}\left(\mathrm{X}^{2}=389.013\right.$, $\mathrm{df}=19, \mathrm{p}=0.0000), \mathrm{S}\left(\mathrm{X}^{2}=250.836, \mathrm{df}=19, \mathrm{p}=0.0000\right)$, and $\mathrm{G}\left(\mathrm{X}^{2}=206.244, \mathrm{df}=19, \mathrm{p}=\right.$ 0.0000). These results are different from Tamimi and Sebastianelli (2017) where they found no significant difference for ESG and E scores while evaluating these CSP attributes for S\&P-500 firms. The data was also segregated into firms belonging to ESI or non-ESI group. Kruskal Wallis test for difference among ESI and non-ESI groups show statistically significant difference only across the $\mathrm{E}\left(\mathrm{X}^{2}=46.891, \mathrm{df}=1, \rho<0.0001\right)$ and $\mathrm{S}\left(\mathrm{x}^{2}=33.363, \mathrm{df}=1, \rho<0.0001\right)$. The same is the result shown by the ANOVA test of equality (see Table 10). The difference of groups is not statistically significant for ESG

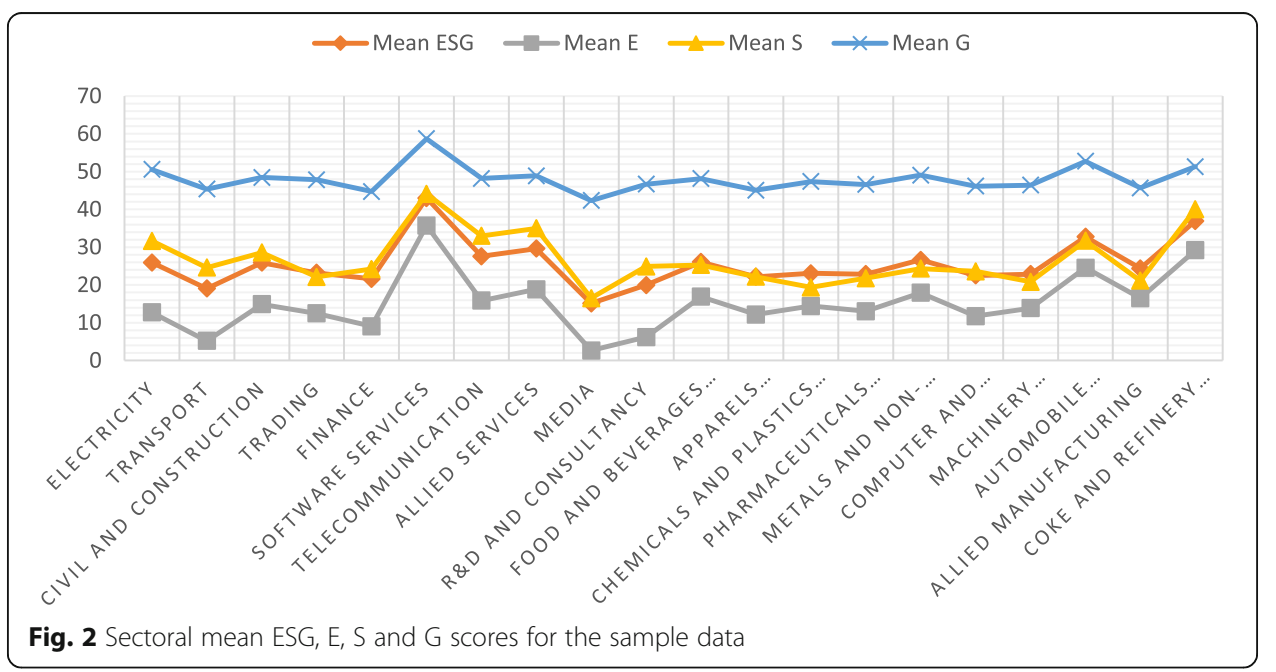


Table 10 ANOVA test of equality based on ESI classification

\begin{tabular}{lllll}
\hline & ESG & E & S & G \\
\hline Observations (N) & 2001 & 2001 & 2001 & 2001 \\
t-test & -0.3719 & -4.0354 & 5.6307 & -1.3865 \\
p-value & 0.7100 & $0.0001^{* * *}$ & $0.0000^{* * *}$ & 0.1657 \\
ANOVA (F-test) & 0.1383 & 16.2846 & 31.7058 & 1.9225 \\
p-value & 0.7100 & $0.0001^{* * *}$ & $0.0000^{* * *}$ & 0.1657 \\
\hline
\end{tabular}

******* Significance at 10,5 and $1 \%$ levels, respectively

and $\mathrm{G}$ revealing that the difference is prominently along the dimensions of $\mathrm{E}$ and $\mathrm{S}$ only. Hence, we have to reject H3 also considering ESG as an overall measure of CSP.

\section{Discussions}

The trend analysis (see Fig. 3) of CSP dimensions reveals that the CSP-ESG doesn't have a vast difference for ESI vs. non-ESI in India, however, non-ESI firms have a higher CSP throughout the sample period except 2009. For both industries, the CSP converges in 2014 and has been continuously increasing with a fixed gap after the same. CSP-E shows an increasing trend overall with a considerable gap in earlier years that has been reducing every year and then becoming consistent from the year 2015. ESI firms were doing better on G dimension than non-ESI firms till 2014 when suddenly the trend reverses with a significant drop for both ESI and non-ESI based firms. After 2015, there has been an increasing trend on this dimension for both groups with a huge gap existing, though ESI based firms are catching up. This change in trend after 2014 may be attributed to changes in Company's Act 2013, that mandatorily required companies to disclose information regarding the activities conducted along the dimensions of E, S, and G in terms of Business Responsibility report, while also making the mandatory expenditure of $2 \%$ profit after tax from the average of last 3 years on CSR activities. Because of this, all types of firms may have aligned their sustainability

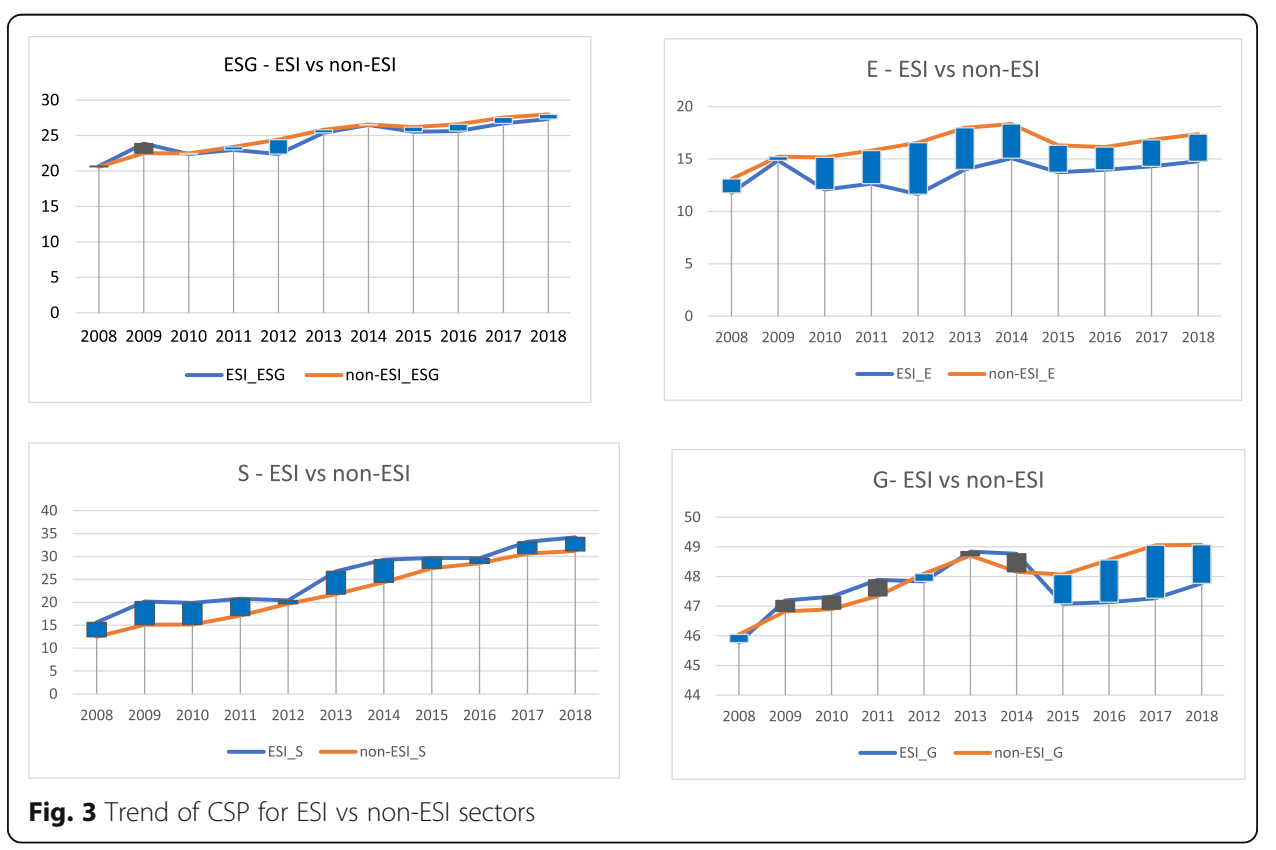


activities along with a standard set of activities along these dimensions leading to an equal gap among the group. The huge change in G may because of the disclosures revealing the actual position of these firms along the attributes of this dimension. On $\mathrm{S}$ dimension, ESI based firms are continuously doing better than non-ESI based firms, which may be because of their enhanced engagement to build a reputation with the community as needed by the nature of the firm's business. Here also, the trend is on an increasing side, with the gap being reduced between both types of firms.

The overall results show different natures of CSP-CFP relationship based on CFP measure chosen as ROA, ROE, or Tobin'sQ with no conclusive causality among the variables in either direction. The regression findings from accounting-based measures show that CSP in terms of combined ESG or E have an inverse impact on CFP whereas $\mathrm{S}$ and $\mathrm{G}$ dimension don't influence the accounting-based measure at all. It means that Indian firms showing better performance on either social or governance aspect will not necessarily have higher financial performance than those showing less sustainability performance. Even if there is some impact it will be because of the environmental dimension, and that too will lower the financial performance. All CSP measures impact market-based CFP (Tobin's Q) or firm value adversely except that it is based on the social dimension. This result supports the classical theory that expenditure on sustainability initiatives impacts the market value though if we observe the coefficients, the impact is not huge. The outcome from GC tests suggests the absence of causality between most of the CSP-CFP variables and vice-versa. The results help us to conclude that Indian firms having higher CSP should not expect their market value to grow when compared to those having lower CSP. This is similar to the results from Tuppura et al. (2016) which suggested differences between the CFP measures used while evaluating the bidirectional causality between CSP and CFP or Jayachandran et al. (2013) who showed that social aspects have a higher influence on CFP measured as Tobin's Q when compared to environmental aspects.

These results are in alignment with findings from many studies like Atan et al. (2018), who did the analysis of ESG attributes on firm profitability and showed that there is no difference in the performance of firms having low or high levels of ESG information. Similar findings from López et al. (2007) suggested that the expenditures incurred for socially responsible activities by a firm can bring financial disadvantage when compared to others in the short term. Soana (2011) couldn't establish any significant link between CSP and CFP for firms based in Italy when CSP was based on ethical ratings and CFP measured by financial ratios whereas Ionescu et al. (2019) reported a weak association between ESG and CFP based on a multi-geographical study. They attributed the difference in results to factors like CFP indices, CSP measures, historical series and argued that CSP-CFP relationship could not be generalized. Similarly, Landi and Sciarelli (2019) couldn't find any statistically significant evidence of ESG with abnormal returns for a sample of Italian firms establishing that, and the market doesn't reward firms with higher CSP. Duque-Grisales and Aguilera-Caracuel (2019) reported a negative relation of CSP measured as E, S, and G independently with CSP for multilatinas. In the Indian context, Aggarwal (2013) couldn't establish a positive relationship between CSR and CFP, Buallay (2019) reported a positive association of CSP measured as E, but negative for S and G. whereas findings from Tyagi and Sharma (2013), showed a neutral though modest negative relationship and argued that if there would be any 
relationship, it will be negative. The significant contribution of the ESG variable into models of ROA showed a moderate negative slope of the relationship. Rodrigo et al. (2016), established a negative linkage between CSP and future CFP where the association was negative bidirectionally, for models using only social models. A neutral link was suggested when using composite and purely environmental model of CSP. O'Higgins and Thevissen (2017) found various aspects of CSP related negatively to CFP where CSP was primarily based on social dimensions and hence suggesting that certain social investments don't pay for particular industries.

Our results contrast the positive association findings for CSP-CFP by different authors (Orlitzky et al. 2003; Artiach et al. 2010; Yu and Zhao 2015; Lee and Pati 2012; Andersen and Dejoy 2011; Chelawat and Trivedi 2016; Dalal and Thaker 2019). Some authors found differing results like CSP showing little sign of directly affecting CFP (Hull and Rothenberg 2008), a positive impact on firm value in countries having high disclosure levels and strong protection for investors (Yu and Zhao 2015), etc. At the individual level for E, S, and G, the social performance was found to be strongly associated with CFP as compared to environmental measures (Orlitzky et al. 2003), whereas in another study, the environmental performance was positively linked to CFP (Moneva and Ortas 2010). Zygadlo et al. (2016) in their extensive research on individual dimensions of CSP found a significant negative result for $\mathrm{E}$ with a significant positive impact for $\mathrm{G}$ and overall suggested that among the three dimensions, social is the least important in this relationship. Our findings are also opposed to the results from Bajic and Yurtoglu (2018) and Chelawat and Trivedi (2016), who reported a positive and highly significant relationship while using the overall ESG score as the predictor. However, for Bajic and Yurtoglu (2018), the analysis of individual scores revealed that only the social aspect of CSP was able to influence CFP with no significant impact for the environment and governance aspects. Teti et al. (2015) conducted a similar analysis for CSP measured by ESG ratings and CFP in terms of stock returns where the findings suggested that at an aggregate level, firms with higher sustainability scores had higher performance over the study period, whereas at the disaggregated level, firms with higher Escores also contributed to higher firm value. The reverse causal analysis strengthened with the GC test for CSP-CFP relationship also couldn't establish that Indian firms with higher CFP lead to more CSP at an aggregate or individual level. Whenever a higher CFP is found to be significant, it is in negative direction for ESG and E based models indicating that a higher CFP certainly doesn't lead to a higher CSP. As CFP increases, Indian firms should expect a decrease in CSP.

These findings for Indian firms support the classical theory (Friedman 1962) that expenditure on sustainability dimension generally lowers the financial performance, and hence, firms showing more sustainability performance are no different from those having lesser sustainability performance. These results may also reflect that the accounting-based measures are primarily based on the book value of the firm, which is based on an intrinsic value derived from strict internal and historical financial status of the firm and hence may not have much impact because of enhanced sustainability performance. Barnett and Salomon (2012) argued that firms might have to undergo a specified period with decreased financial performance as they invest in social performance. In India. as the investments in social dimension seem to increase post-2015 (probably owing to changes in Company's Act 2013) only, it may be possible that the investments 
done by Indian corporates towards sustainability dimensions may take some time to reflect in their financial performance. Possibly, the current period in sample data is not sufficient for Indian firms to show a significant impact on CFP because of these recent investments post the changes in the Company's Act 2013.

Another interesting finding from this study is that older the firm, more adverse, is its impact on the accounting-based CFP whereas the effects of size on these measures are certainly in a positive direction. This means that larger sized firms will have more impact on the CFP for the Indian firms and hence are predictable to be more profitable. Market risk or volatility is directly related to the accounting-based measures, and interestingly, it impacts ROA positively but ROE negatively. This is aligned with findings where environmental performance was negatively associated with firm risk (Muhammad et al. 2015), and CSR was negatively related to systematic firm risk (Oikonomou et al. 2012). It may be because risk is embedded in the valuation of equity whereas it doesn't have any inherent impact on ROA based on the actual asset of the firm. The results suggest that as the risk or volatility increases, it reduces the CFP of a firm when measured in terms of ROE. R\&D intensity is found to be not affecting these measures except in the case of CSP-E, supporting the classical theory that expenditure on R\&D intensity is primarily towards improving environment based CSP but adversely impacts the CFP. At an individual level, CSP in terms of environment helps firms to reduce their financial risk as investors view them providing an insurance-like protection (Muhammad et al. 2015).

As is the case with accounting-based measures, regressions results suggest that both firm-size and firm-age have adverse and positive impacts respectively on the market value of the firm. These results reveal that larger and younger firms are valued more than firms that are smaller and older. This may be because younger firms may be more aligned with current market realities and agile and hence increased size may have better perception from the market, whereas older firms are bound by their processes and are not able to move fast even though small and therefore are not valued by the market. Also, both R\&D intensity and market risk don't impact the market value for the CSP measures considered in the models, which is somewhat difficult to comprehend since market risk should have some impact on market-based CFP, which is not a case with the current sample. Results on $R \& D$ intensity are against the earlier findings from Moneva and Ortas (2010) who showed that firms with a higher level of the environmental performance show better CFP. These results are also aligned with the conclusion from Artiach et al. (2010), who revealed the firm-size to be consistently linked to a high level of CSP and showing that firms with higher CSP are larger and have a higher ROE than traditional firms. Our findings also don't support the results from Jayachandran et al. (2013), who suggested that firm-size was negatively related to Tobin'sQ for both $\mathrm{S}$ and $\mathrm{E}$ based models.

Tuppura et al. (2016) suggested that the nature of CSP-CFP linkage differs according to the industry whereas Zygadlo et al. (2016) emphasized that this relationship should be validated in different countries. Yet another argument to explain this kind of relationship can be that the interaction between firms and societies is so multifaceted that a straightforward link between CSP and CFP seems unlikely (Baird et al. 2012). One may argue that the results of CSP-CFP are based on the business environment and culture of a country based on which the results may vary. 


\section{Implications}

There are multiple implications of this research. These findings will be helpful for academicians to evaluate the causality and impact of CSP-CFP relationship in a developing country like India where earlier, sustainability effort by corporates was mostly driven by a moralistic perspective. Post-globalization, it is driven by a strategic perspective, and recently, CSR spending has been made mandatory by the regulatory authority. Our results align with different inconclusive findings in literature for CSP-CFP till date because of strong results supporting non-causality among CSP-CFP variables. These results may put some more light on additional variables that should be considered during these studies. Corporate managers may use this study to understand why a higher CSP is not providing enough return on the CFP front and can give some guidance on whether the focus should be on an individual dimension or aggregate ESG for investments done on sustainability. Investors using ESG scores may evaluate if socially responsible investments are the right thing to do in the Indian environment since it may lead to a decrease in financial value. Also, investors using Bloomberg scores may like to evaluate whether investments done based on these scores reflect actual CSP for the firm, as the parameters considered by Bloomberg may not be exhaustive, and it is tough to assess the quality of this information. This study provides policy-makers guidance on providing different incentives to firms based on the investments done in different ESG dimensions to help the firms increase financial performance. If the financial performance doesn't increase because of higher CSP, it may not be an incentive for the firms to invest in sustainability efforts moving forward.

\section{Limitations and future work}

This research is not without limitations. As CSP is measured using Bloomberg ESG scores based on a proprietary method, we may not be sure whether it has exhaustive coverage for CSP factors. This study can be enhanced further by using reputational indices as the non-financial performance measure bringing the intangible benefits gathered from higher CSP into the CSP-CFP relationship paradigm. This study has only been conducted for Indian firms and can be extended further to have a cross-country comparative study where the results can be compared among the developed and developing economic world. We have used multiple regression methods for evaluating the relationship. In the future, with more variables included for both CSP and CFP, researchers can use path analysis to assess the direction and intensity of relationships among different variables that may evolve from the intrinsic connection in data itself. Such research may reveal more details on this relationship in the Indian context. As the literature suggests, the CSP-CFP relationship is highly context-driven, and the results vary based on the contextual variables where the country's business environment may be one of the critical factors. The research may also be enhanced by considering some mediating or moderating contextual variables to see their impact. Differing patterns have been observed in countries with diverse business and regulatory environment. It needs to be seen whether an exhaustive cross-country comparison study is required to establish a generalized result for the CSP-CFP relationship.

\section{Conclusions}

This article presents an in-depth study of the CSP-CFP relationship for a sample of Indian firms. CSP variables have been considered at both aggregate and disaggregate 
levels of environmental, social and governance performance based on the index created by a third-party agency. CFP has been evaluated in both accounting (ROA and ROE) as well as market (Tobin's Q) based measures. We have used the FE regression method to do the analysis based on the outcome of the Hausman test and GC for assessing the bidirectional causality among CSP-CFP variables. A sectoral level analysis is also done based on the trend and dividing the Indian firms in ESI vs non-ESI sectors. Our overall findings reveal an absence of causality among most of the CSP-CFP variables in either direction except some causality detected for non-ESI firms. They suggest that the CSP-CFP linkage is insignificant for Indian firms when CFP is measured in terms of accountingbased measures except for CSP measured as ESG-score and E-score with ROA. The relation is found to be significant for all CSP measures except S-score when CFP is a marketbased measure. This relationship has a negative/adverse impact on CSP-CFP linkage in both cases, which means that Indian firms don't get the financial performance benefits of investments done for sustainability. Our findings with mostly insignificant results for this relation also means that firms with higher or lower CSP on ESG dimensions will perform likewise in terms of CFP. Similar findings found for the reverse direction, where the impact of CFP on CSP is found either insignificant or negative. This study showed through reverse causal analysis that firms with higher CFP are not necessarily leading to more CSP, rather an increase in CFP may lead to a decrease in CSP.

The results are in line with earlier findings for Indian firms as covered in the discussion section. There may be multiple reasons for the same. First, Indian firms are not disclosing all sustainability efforts effectively and hence not being accounted for by the rating agencies. Second reason may be that Indian firms may be spending money in specific sustainability dimensions only (see Jha and Rangarajan 2020) not aligned with the coverage of CSP attributes measured by Bloomberg. Lastly, there may also be a misalignment between market expectations for sustainability attributes coverage and Indian firms' efforts on various sustainability dimensions. The findings of this study are not aligned with many classical studies done in developed countries that support the positive direction of the CSP-CFP relationship but is aligned with many studies that support the neutral or negative direction of this relationship. The study reveals interesting results for ESI and non-ESI firms in India, suggesting that the CSP is on an increasing trend after 2015, but the growth in social dimension is maximum for ESI as compared with non-ESI firms.

\section{Acknowledgements}

We would like to sincerely thank Dr. Rakesh Kumar Mishra of Indian Oil Corporation for his valuable feedback during the development of this paper.

\footnotetext{
About the authors

Mr. Milind Kumar Jha is a PhD scholar at the Indian Institute of Foreign Trade, New Delhi, working in the area of Business Strategy and General Management. The author is holding PGDM from the Indian Institute of Management (IIM) Lucknow in Finance and Strategy. He also holds a B. Tech. in Computer Science and Engineering. He has more than 16 years of experience in the areas of Software development, Quality engineering, and Program Management working with many multinational companies with experience of multiple geographies and cultures. The author is presently working with Adobe Systems as a Group Program Manager. Milind Kumar Jha is the corresponding author and can be contacted at milinddbg@gmail.com

Dr. K. Rangarajan is a Professor and head of IIFT, Kolkata. He has guided many doctoral theses and actively involved in the research of Global Business Strategy. His expertise includes Business Strategy and Strategic Planning in general and internationalization of SMEs and Management of Trade Support Institutions, including Trade Promotion Organizations. His areas of interest are Organizational Restructuring, Corporate and Business Level Strategies and Cluster Development. He has served as National Expert for UNIDO, Austria, ILO and Common Wealth Secretariat in different projects. He serves in several industry associations and academic institutions in various capacities.
} 


\section{Authors' contributions}

MKJ conceptualized the study and KR provided validation on the conceptualized model. MKJ collected the data, conducted the analysis, and documented the results. KR helped in writing the results and validation of the results with data. MKJ finalized the analysis section. All authors, read, edited and approved the final manuscript.

\section{Funding}

Not applicable.

\section{Availability of data and materials}

Yes, we can provide the supporting data if required.

\section{Competing interests}

The authors declare that they have no competing interests.

\section{Author details}

${ }^{1}$ Indian Institute of Foreign Trade, New Delhi, India. ${ }^{2}$ Indian Institute of Foreign Trade, Kolkata, India.

Received: 26 November 2019 Accepted: 13 May 2020

Published online: 29 May 2020

\section{References}

Aggarwal M (2013) Corporate social responsibility and financial performance linkage evidence from Indian companies. Int J Manag Development Stud 2(7):12-24

Agrawal N, Banda M, Marshall A, Mehrotra N, Patrao C (2017) How India can be essential to the global ecosystem economy. Strateg Leadersh 45(4):33-39

Ahmad S, Wong KY, Rajoo S (2019) Sustainability indicators for manufacturing sectors: a literature survey and maturity analysis from the triple-bottom line perspective. J Manuf Technol Manag 30(2):312-334

Ameer R, Othman R (2012) Sustainability practices and corporate financial performance: a study based on the top global corporations. J Bus Ethics 108(1):61-79

Andersen ML, Dejoy JS (2011) Corporate social and financial performance: the role of size, industry, risk, R\&D and advertising expenses as control variables. Bus Soc Rev 116(2):237-256

Appelbaum, S. H., Calcagno, R., Magarelli, S. M., \& Saliba, M. (2016). A relationship between corporate sustainability and organizational change (Part One), Industrial and Commercial Training, Vol. 48 Iss 1 pp. 16-23

Artiach T, Lee D, Nelson D, Walker J (2010) The determinants of corporate sustainability performance. Account Finance 50(1): $31-51$

Atan R, Alam MM, Said J, Zamri M (2018) The impacts of environmental, social, and governance factors on firm performance: panel study of Malaysian companies. Manag Environ Quality Int J 29(2):182-194

Babu A (2018) Causality between foreign direct investments and exports in India. Theoretical \& Applied Economics 25(4):131140

Baird PL, Geylani PC, Roberts JA (2012) Corporate social and financial performance re-examined: industry effects in a linear mixed model analysis. J Bus Ethics 109(3):367-388

Bajic S, Yurtoglu B (2018) Which aspects of CSR predict firm market value? J Capital Markets Stud 2(1):50-69

Bansal P (2005) Evolving sustainably: a longitudinal study of corporate sustainable development. Strateg Manag J 26(3):197218

Barnett ML, Salomon RM (2012) Does it pay to be really good? Addressing the shape of the relationship between social and financial performance. Strateg Manag J 33(11):1304-1320

Berman SL, Wicks AC, Kotha S, Jones TM (1999) Does stakeholder orientation matter? The relationship between stakeholder management models and firm financial performance. Acad Manage J 42(5):488-506

Bhatia A, Tuli S (2017) Corporate attributes affecting sustainability reporting: an Indian perspective. Int J Law and Manag 59(3):322-340

Bloomberg Disclosure Score. (2019). Behind the Bloomberg Disclosure Score, viewed 30th September, 2019, https:// frameworkesg.com/bloomberg-esg-disclosure-scores-behind-the-terminal/

Branco MC, Rodrigues LL (2006) Corporate social responsibility and resource-based perspectives. J Bus Ethics 69(2):111-132

Buallay A (2019) Is sustainability reporting (ESG) associated with performance? Evidence from the European banking sector. Manag Environ Quality Int J 30(1):98-115

Carroll AB, Shabana KM (2010) The business case for corporate social responsibility: a review of concepts, research and practice. Int J Manag Rev 12(1):85-105

Chakrabarty S, Wang L (2012) The long-term sustenance of sustainability practices in MNCs: a dynamic capabilities perspective of the role of R\&D and internationalization. J Bus Ethics 110(2):205-217

Chatterji AK, Levine DI, Toffel MW (2009) How well do social ratings actually measure corporate social responsibility? J Econ Manag Strategy 18(1):125-169

Chelawat H, Trivedi IV (2016) The business value of ESG performance: the Indian context. Asian J Business Ethics 5(1-2):195210

Cheon O, An SH (2017) Blowing in the wind: a study for granger causality between managerial strategy and organizational performance. Public Manag Rev 19(5):686-704

Christofi A, Christofi P, Sisaye S (2012) Corporate sustainability: historical development and reporting practices. Manag Res Rev 35(2):157-172

CPCB, (2019) viewed 30th September, 2019, https://cpcb.nic.in/index.php

Dalal KK, Thaker N (2019) ESG and corporate financial performance: a panel study of Indian companies. IUP J Corp Gov 18(1): 44-59

Davis JH, Schoorman FD, Donaldson L (1997) Toward a stewardship theory of management. Acad Manage Rev 22(1):20-47 
Davis K (1973) The case for and against business assumption of social responsibilities. Acad Manage J 16(2):312-322 Delai I, Takahashi S (2011) Sustainability measurement system: a reference model proposal. Soc Responsibility J 7(3):438-471 Deodhar SY (2016) Trapping India's CSR in a legal net: will the mandatory trusteeship contribute to triple bottom line? Vikalpa 41(4):267-274

Deswanto RB, Siregar SV (2018) The associations between environmental disclosures with financial performance, environmental performance, and firm value. Soc Responsibility J 14(1):180-193

Dhanesh GS (2015) Why corporate social responsibility? An analysis of drivers of CSR in India. Manag Commun Q 29(1):114129

Dienes D, Sassen R, Fischer J (2016) What are the drivers of sustainability reporting? A systematic review. Sustainability Account Manag Policy J 7(2):154-189

Donaldson T, Preston LE (1995) The stakeholder theory of the corporation: concepts, evidence, and implications. Acad Manage Rev 20(1):65-91

Du S, Vieira ET (2012) Striving for legitimacy through corporate social responsibility: insights from oil companies. J Bus Ethics 110(4):413-427

Duque-Grisales, E., \& Aguilera-Caracuel, J. (2019). Environmental, social and governance (ESG) scores and financial performance of Multilatinas: Moderating effects of geographic international diversification and financial slack. J Bus Ethics, $1-20$

Elkington, J. (2011). Enter the triple bottom line. 2004. http://www.Johnelkington.Com/TBL-elkington-chapter.Pdf. Acesso em, 11,12

Emirmahmutoglu F, Balcilar M, Apergis N, Simo-Kengne BD, Chang T, Gupta R (2016) Causal relationship between asset prices and output in the United States: evidence from the state-level panel granger causality test. Reg Stud 50(10):1728-1741

Epstein MJ, Bohuvac AR (2014) Making sustainability work: best practices in managing and measuring corporate social, environmental and economic impacts. Routledge

ESG Data, 2019. Viewed 30th September, 2019, https://www.bloomberg.com/impact/products/esg-data/

Fallah MA, Mojarrad F (2019) Corporate governance effects on corporate social responsibility disclosure: empirical evidence from heavy-pollution industries in Iran. Soc Responsibility J 15(2):208-225

Famiyeh S (2017) Corporate social responsibility and firm's performance: empirical evidence. Soc Responsibility J 13(2):390-406

Freeman RE (2010) Strategic management: a stakeholder approach. Cambridge university press

Friedman M (1962) Capitalism and freedom, (with new preface in the 40th anniversary edition in 2002)

Gibson K (2012) Stakeholders and sustainability: An evolving theory. J Bus Ethics 109(1):15-25

Goyal P, Rahman Z, Kazmi AA (2013) Corporate sustainability performance and firm performance research: literature review and future research agenda. Manag Decis 51(2):361-379

Granger CWJ (1969) Investigating causal relations by econometric models and cross-spectral methods. Econometrica 37(3): $424-438$

Greenberg M (2013) What on earth is sustainable?: toward critical sustainability studies. Boom: A Journal of California 3(4):54-66

Gregory A, Whittaker J (2013) Exploring the valuation of corporate social responsibility - a comparison of research methods. J Bus Ethics 116(1):1-20

Grewatsch S, Kleindienst I (2017) When does it pay to be good? Moderators and mediators in the corporate sustainabilitycorporate financial performance relationship: a critical review. J Bus Ethics 145(2):383-416

Hillman AJ, Keim GD (2001) Shareholder value, stakeholder management, and social issues: what's the bottom line? Strateg Manag J 22(2):125-139

Huber, B. M., Comstock M., Polk D., \& Wardwell (2017), ESG reports and ratings: what they are, why they matter, viewed 30th September, 2019, https://corpgov.law.harvard.edu/2017/07/27/esg-reports-and-ratings-what-they-are-why-they-matter/

Hull CE, Rothenberg S (2008) Firm performance: the interactions of corporate social performance with innovation and industry differentiation. Strateg Manag J 29(7):781-789

Ionescu GH, Firoiu D, Pirvu R, Vilag RD (2019) The impact of ESG factors on market value of companies from travel and tourism industry. Technol Econ Dev Econ 25(5):820-849

Jain R, Winner LH (2016) CSR and sustainability reporting practices of top companies in India. Corp Commun Int J 21(1):36-55

Jayachandran S, Kalaignanam K, Eilert M (2013) Product and environmental social performance: varying effect on firm performance. Strateg Manag J 34(10):1255-1264

Jayakumar T (2016) From philanthropy to strategic corporate sustainability: a case study in India. J Bus Strateg 37(6):39-50

Jensen MC, Meckling WH (1976) Theory of the firm: managerial behavior, agency costs and ownership structure. J Financ Econ 3(4):305-360

Jha, M. K., \& Rangarajan, K. (2020). The approach of Indian corporates towards sustainable development: An exploration using sustainable development goals based model. Sustainable Development, https://doi.org/10.1002/sd.2053.

Kengkathran S (2018) A literature review on the impact of environmental, Social and Governance (ESG) Disclosure on Financial Performance of Energy Companies in Asean Global Business \& Management Research, p 10

Kilian T, Hennigs N (2014) Corporate social responsibility and environmental reporting in controversial industries. Eur Bus Rev 26(1):79-101

Kónya L (2006) Exports and growth: granger causality analysis on OECD countries with a panel data approach. Econ Model 23(6):978-992

Lacy P, Hayward R (2011) A new era of sustainability in emerging markets? Insights from a global CEO study by the United Nations global compact and Accenture. Corporate Governance: Int J Business Society 11(4):348-357

Landi G, Sciarelli M (2019) Towards a more ethical market: the impact of ESG rating on corporate financial performance. Soc Responsibility J 15(1):11-27

Lee J, Pati N (2012) New insights on the operational links between corporate sustainability and firm performance in service industries. Int J Business Insights Transformation 4(1):80-93

Legendre S, Coderre F (2013) Determinants of GRI G3 application levels: the case of the fortune global 500. Corp Soc Respon Environ Manag 20(3):182-192

López MV, Garcia A, Rodriguez L (2007) Sustainable development and corporate performance: a study based on the Dow Jones sustainability index. J Bus Ethics 75(3):285-300 
Lourenço IC, Branco MC, Curto JD, Eugénio T (2012) How does the market value corporate sustainability performance? J Bus Ethics 108(4):417-428

Lourenço IC, Callen JL, Branco MC, Curto JD (2014) The value relevance of reputation for sustainability leadership. J Bus Ethics 119(1):17-28

Lu W, Taylor ME (2015) Which factors moderate the relationship between sustainability performance and financial performance? A meta-analysis study. J Int Account Res 15(1):1-15

Luke TW (2013) Corporate social responsibility: an uneasy merger of sustainability and development. Sustain Dev 21(2):83-91

Luo X, Wang H, Raithel S, Zheng Q (2015) Corporate social performance, analyst stock recommendations, and firm future returns. Strateg Manag J 36(1):123-136

Malhotra G (2019) India and US stock indexes-a cointegration and granger-causality test. New Zealand Journal of Applied Business Research 17(1):29-40

Marom IY (2006) Toward a unified theory of the CSP-CFP link. J Bus Ethics 67(2):191-200

McWilliams A, Siegel D (2001) Corporate social responsibility: a theory of the firm perspective. Acad Manage Rev 26(1):117127

Melo T (2012) Slack-resources hypothesis: a critical analysis under a multidimensional approach to corporate social performance. Soc Responsibility J 8(2):257-269

Mishra S, Suar D (2010) Does corporate social responsibility influence firm performance of Indian companies? J Bus Ethics 95(4):571-601

Moneva JM, Ortas E (2010) Corporate environmental and financial performance: a multivariate approach. Ind Manag Data Syst 110(2):193-210

Muhammad N, Scrimgeour F, Reddy K, Abidin S (2015) The impact of corporate environmental performance on market risk: the Australian industry case. J Bus Ethics 132(2):347-362

Nagel S, Hiss S, Woschnack D, Teufel B (2017) Between efficiency and resilience: the classification of companies according to their sustainability performance. Historical Social Research/Historische Sozialforschung:189-210

NIC 2008 Codes. (2019), NIC 2008 Codes \& its Descriptions, viewed 30th September, 2019, http://www.mospi.nic.in/sites/ default/files/6ec_dirEst/ec6_nic_2008_code.html

O'shaughnessy KC, Gedajlovic E, Reinmoeller P (2007) The influence of firm, industry and network on the corporate social performance of Japanese firms. Asia Pac J Manag 24(3):283-303

O'Higgins E, Thevissen T (2017) Revisiting the corporate social and financial performance link: a contingency approach. Bus Soc Rev 122(3):327-358

Oikonomou I, Brooks C, Pavelin S (2012) The impact of corporate social performance on financial risk and utility: a longitudinal analysis. Financ Manag 41(2):483-515

Orlitzky M, Schmidt FL, Rynes SL (2003) Corporate social and financial performance: a meta-analysis. Organ Stud 24(3):403441

Oumarou I, Maiga OA (2019) A causal relationship between trade, foreign direct investment and economic growth in Niger. J Soc Econ Stat 8(2):24-38

Peloza J (2009) The challenge of measuring financial impacts from investments in corporate social performance. J Manag 35(6):1518-1541

Peng CW, Yang ML (2014) The effect of corporate social performance on financial performance: the moderating effect of ownership concentration. J Bus Ethics 123(1):171-182

Petrovska K (2019) Using granger causality to determine interconnectedness in unlisted banking markets. J of Acco And Fina 19(9)

Placet M, Anderson R, Fowler KM (2005) Strategies for sustainability. Res Technol Manag 48(5):32-41

Porter ME, Van der Linde C (1995) Toward a new conception of the environment-competitiveness relationship. J Econ Perspect 9(4):97-118

Quazi A, Richardson A (2012) Sources of variation in linking corporate social responsibility and financial performance. Soc Responsibility J 8(2):242-256

Rodrigo P, Duran IJ, Arenas D (2016) Does it really pay to be good, everywhere? A first step to understand the corporate social and financial performance link in Latin American controversial industries. Business Ethics: A European Review 25(3): 286-309

Saeidi SP, Sofian S, Saeidi P, Saeidi SP, Saaeidi SA (2015) How does corporate social responsibility contribute to firm financia performance? The mediating role of competitive advantage, reputation, and customer satisfaction. J Bus Res 68(2):341350

Searcy C (2012) Corporate sustainability performance measurement systems: a review and research agenda. J Bus Ethics 107(3):239-253

Sharma S (2013) Corporate social responsibility in India-the Emerging Discourse \& Concerns. Indian J Industrial Relations:582596

Sharma SG (2009) Corporate social responsibility in India: An overview. Int Lawyer 43(4):1515-1533

Sikdar SK (2003) Sustainable development and sustainability metrics. AICHE J 49(8):1928-1932

Soana MG (2011) The relationship between corporate social performance and corporate financial performance in the banking sector. J Bus Ethics 104(1):133

Sözen I, Tufaner MB (2019) The RELATIONSHIP BETWEEN r\&d expenditures and innovative development: a panel data analysis for selected OECD countries. Marmara Üniversitesi İktisadi ve İdari Bilimler Dergisi 41(2):493-502

Steurer R, Langer ME, Konrad A, Martinuzzi A (2005) Corporations, stakeholders and sustainable development I: a theoretical exploration of business-society relations. J Bus Ethics 61(3):263-281

Stubbs W, Rogers P (2013) Lifting the veil on environment-social-governance rating methods. Soc Responsibility J 9(4):622-640

Suchman MC (1995) Managing legitimacy: strategic and institutional approaches. Acad Manage Rev 20(3):571-610

Sung Kim, W., \& Oh, S. (2019). Corporate social responsibility, business groups and financial performance: a study of listed Indian firms. Economic Research-Ekonomska Istraživanja, 32(1), 1777-1793

Surroca J, Tribó JA, Waddock S (2010) Corporate responsibility and financial performance: the role of intangible resources. Strateg Manag J 31(5):463-490 
Tamimi N, Sebastianelli R (2017) Transparency among S\&P 500 companies: an analysis of ESG disclosure scores. Manag Decis 55(8):1660-1680

Teti E, Dell'Acqua A, Etro LL, Andreoletti LB (2015) Corporate social performance and portfolio management. J Manag Dev 34(9):1144-1160

Tuppura A, Arminen H, Pätäri S, Jantunen A (2016) Corporate social and financial performance in different industry contexts: the chicken or the egg? Soc Responsibility J 12(4):672-686

Tyagi R, Sharma AK (2013) Corporate social performance and corporate financial performance: a link for the Indian firms. Issues Soc Environ Accounting, ISSN 591:4-29

Ullmann AA (1985) Data in search of a theory: a critical examination of the relationships among social performance, social disclosure, and economic performance of US firms. Acad Manage Rev 10(3):540-557

Van Beurden P, Gössling T (2008) The worth of values-a literature review on the relation between corporate social and financial performance. J Bus Ethics 82(2):407

Vitezić N, Vuko T, Mörec B (2012) Does financial performance have an impact on corporate sustainability and csr disclosure-a case of croatian companies. J Business Manag 5:40-47

Von Hauff M, Veling A (2018) India's need for a sustainability strategy: creating a stable and balanced development. Ane Books Pvt. Limited, New Delhi

Waddock SA, Graves SB (1997) The corporate social performance-financial performance link. Strateg Manag J 18(4):303-319

Wang S, Gao Y (2016) What do we know about corporate social responsibility research? A content analysis. The Irish Journal of Management 35(1):1-16

Wilkinson A, Hill M, Gollan P (2001) The sustainability debate. Int J Oper Prod Manag 21(12):1492-1502

Wong A (2014) Corporate sustainability through non-financial risk management. Corp Gov 14(4):575-586

Wood DJ (1991) Corporate social performance revisited. Acad Manage Rev 16(4):691-718

Yu M, Zhao R (2015) Sustainability and firm valuation: an international investigation. Int J Account Inf Manag 23(3):289-307

Yusoff WFW, Alhaji IA (2012) Insight of corporate governance theories. J Bus Manag 1(1):52-63

Zahid M, Ghazali Z (2017) Corporate sustainability practices and Firm's financial performance: the driving force of integrated management system. Glob Bus Manag Res 9(1):479-491

Zygadlo DK, Slonski T, Zawadzki B (2016) The market value of CSR performance across sectors. Eng Econ 27(2):230-238

\section{Publisher's Note}

Springer Nature remains neutral with regard to jurisdictional claims in published maps and institutional affiliations.

\section{Submit your manuscript to a SpringerOpen ${ }^{\circ}$ journal and benefit from:}

- Convenient online submission

- Rigorous peer review

- Open access: articles freely available online

- High visibility within the field

- Retaining the copyright to your article

Submit your next manuscript at $\boldsymbol{\nabla}$ springeropen.com 